\title{
Some Hitherto Unknown Fragments of Utpaladeva's Vivrti (II): Against the Existence of External Objects
}

\author{
Isabelle Ratié
}

\section{Fragments of Utpaladeva's Vivrti in Marginal Annotations of Manuscripts Belonging to the Pratyabhijñā Corpus}

Raffaele Torella's discovery and remarkable edition of the only (and very incomplete) manuscript of the Vivrti thus far known ${ }^{1}$ has enabled us to determine with certainty that some marginal annotations in manuscripts of Abhinavagupta's İsvarapratyabhijñāvimarśinī (henceforth ĪPV) and İśvarapratyabhijñāvivrtivimarśinī (henceforth ĪPVV) regularly quote Utpaladeva's lost work. Nine of the İPV manuscripts that I have been able to consult contain such quotations; $^{2}$ two İPVV manuscripts ${ }^{3}$ known to me bear several fragments, the most important of which is by far the lengthiest Vivrti fragment known to date (including the one found in the codex unicus edited by Raffaele Torella), covering three Vivrti chapters; ${ }^{4}$ and two manuscripts of the Ísvarapratyabhijñāvrtti (henceforth Vrtti) have been shown to contain some much shorter Vivrti quotations. ${ }^{5}$ The following pages are an attempt to edit and translate

1 The manuscript as it stands now only covers verses 1.3.6 to 1.5.3. See Torella 1988 (this first part of the fragment was in fact edited from a transcript of the original manuscript $\mathrm{D}$ later found by R. Torella in the National Archives of India and used for the edition of the remaining parts of the fragment), and Torella 2007a, 2007b, 2007c and 2007d.

2 For a list of parallels between marginal annotations in $\mathrm{D}_{2}$, soAs and $\mathrm{S}_{3}$ and the fragment edited by R. Torella, see Ratié 2016 . Five other ĪPv manuscripts-namely J ${ }^{\mathrm{R}}, \mathrm{S}_{2}, \mathrm{~S}_{5}, \mathrm{~S}_{7}, \mathrm{~S}_{9}-$ have been shown to contain such fragments in Ratié 2016b, and one more (S15) in Ratié forthcoming (see also below).

3 S12 and J11.

4 On this discovery, see Ratié 2017 and Ratié forthcoming.

5 See Kawajiri 2016 and 2016b for a diplomatic edition of marginal annotations containing Vivrti quotations in a Vrtti manuscript from Lucknow in Devanāgarī script. Note, however, that Sig (a Śāradā manuscript used by Raffaele Torella for his edition of the Vrtti) also contains many Vivrti fragments. It is described in Torella 2002, l-li (under siglum N) as "profusely annotated by a different hand with single glosses or long passages (mostly drawn from the I PV) between the lines and often entirely covering the margins." Indeed, many of these quota- 
some brief marginal annotations borrowed from Utpaladeva's lost Vivrti on İsvarapratyabhijñā $k \bar{a} r i k \bar{a}$ (henceforth İPK) 1.5 .6 and 1.5.8-9. ${ }^{6}$

This is no easy task, because very little is known of the source(s), purpose(s) and history of these annotations, ${ }^{7}$ and because most of the time their authors do not specify whether they are quoting ${ }^{8}$ — and if so, which text ${ }^{9}$ —or rather giving a comment of their own. We can quite safely assume that these annotations are indeed genuine quotations from the Vivrti whenever we can find in them a sequence of words corresponding exactly to the pratikas in Abhinavagupta's I PvV. However, Abhinavagupta's quotations of the Vivrti are sometimes so brief that we cannot always reach such a high level of probability, as can be seen from one problematic instance below. ${ }^{10}$ Besides, the marginal

tions are from the ĪPV; but some are Vivrti fragments, as shown in Ratié forthcoming (see also Ratié 2018b, Appendix I). S19 was not taken into account here, not because it would be irrelevant (its margins bear several fragments on İPK 1.5.6-9, and interestingly, most of them are not found in the İPV and ĪPVV manuscripts used below), but because unfortunately, I made this discovery too late to incorporate the new findings in this article.

6 So far I have not found any Vivrti quotation on İPK 1.5.7 in ĪPV or ĪPVV manuscripts. It should also be noted that S12, to which I only recently had access, bears the fragment edited in Ratié 2016, 239-240 from marginal annotations in $S_{3}$. In $S_{12}$ the fragment appears in the margins of folios 119A-120B. The missing words in $\mathrm{S}_{3}$ (Ratié 2016, 239, note 35) appear as tathā carati in S12; the compound parajñānavișayabhāvagamanābhisandhir (ibid., 239, §1, last line) has the wrong reading parajñānaparajñānavișayabhāvagamanābhisandhir; $\mathrm{S}_{12}$ shares with $\mathrm{S}_{3}$ the wrong readings ${ }^{9}$ vyavahārādy ${ }^{\circ}$ instead of จyāhārā $d y^{\circ}$ (see ibid., 239, note 36 and 37 ), and occasionally reads ${ }^{\circ}$ yyavahārāady ${ }^{\circ}$ where $\mathrm{S}_{3}$ has the right reading ${ }^{\circ}$ ryāhārādy ${ }^{\circ}$ (in tajjñānagataryāhārāady ${ }^{\circ}$, ibid., 239, §2, line 5); it reads yadi where $\mathrm{S}_{3}$ has yad iha (ibid., 239, § 2, line 6-I had conjectured yadi hi); it also has ābhāsabhedahetutva ${ }^{\circ}$ instead of ābhāsabhede hetutva ${ }^{\circ}$ (ibid., 240, §5, line 5); it shares with $S_{3}$ the wrong readings yathāvabhāsānām (see ibid., 240, note 41) and pramātrprābhāsaparyavasānam (see ibid., 240, note 42); finally, it reads nāpi pratibodhitā ekaiva instead of S3's nādhipratitvocitaikaiva (and my conjecture nädhipatitvocitaikaiva).

7 See Formigatti 2011 and Ratié 2018b. Formigatti 2011 (a very interesting study of marginal annotations in Sanskrit manuscripts from northern India and Nepal) bears in part on İ PV manuscripts; unfortunately it makes no mention of Vivrti fragments, although at least one of the manuscripts examined, $S_{7}$ (= S9 in the present paper), contains quotations from Utpaladeva's detailed auto-commentary (see Ratié 2016b). The reason for this is that due to the length of the İPV, Formigatti chose to confine his research to the annotations on the first chapter, which are apparently devoid of such quotations.

8 This happens, however: see Ratié 2016,228 , note 10 , and below, note 58 .

9 The marginal annotations most often quote from Utpaladeva's Vrtti and Abhinavagupta's I PVV, but other works are occasionally cited, including Śaiva texts (such as the Śivadrșți) as well as Buddhist works (e.g. Dharmakīrti's Sambandhaparīkșā) or Brahmanical treatises (e.g. Jayanta's Nyāyamañjarī): see Ratié 2017, 165 .

See fragment no. 6? on ĪPK 1.5.8-9. 


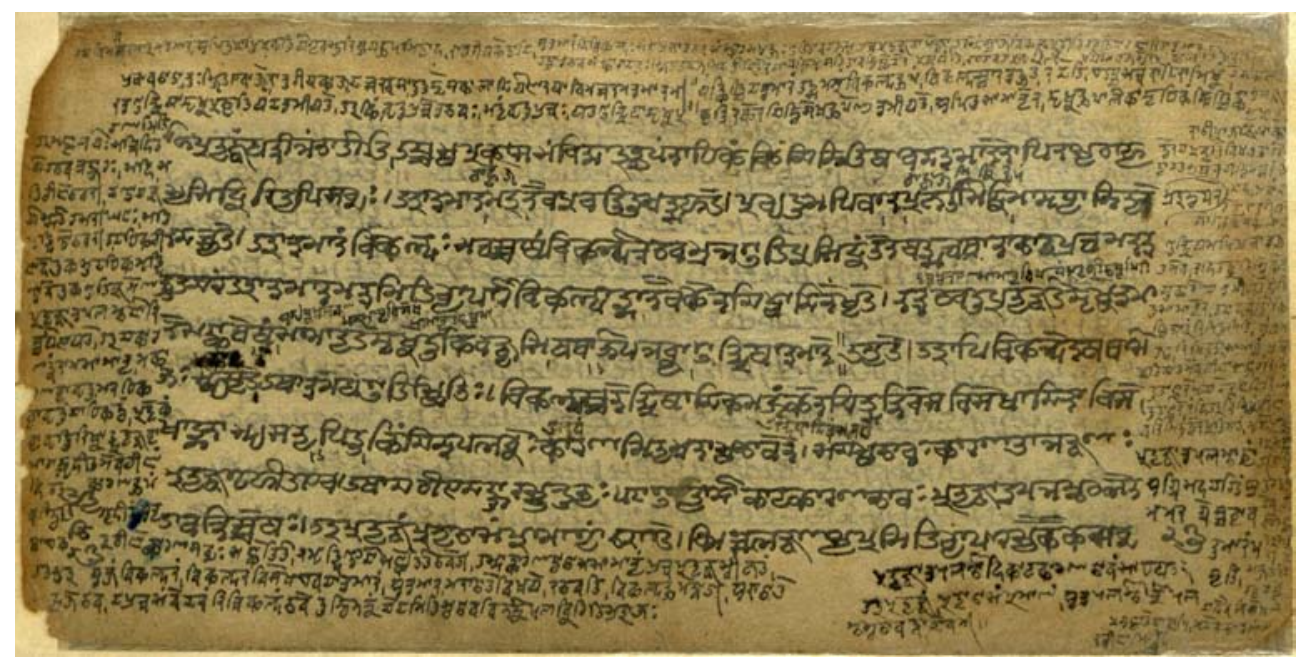

FIGURE 5.1 Manuscript $S_{3}$ of Abhinavagupta's İśvarapratyabhijñāvimarśinī (f. 43A), with fragments 4 and 5 of Utpaladeva's Vivrti on vv. 1.5.8-9 in the top and right margins PHOTOGRAPH: NATIONAL ARCHIVES OF INDIA

annotations are sometimes barely legible, and Utpaladeva's prose is difficult. For all these reasons, both the edition and translation given here are only tentative.

The overall context of the fragments presented here is a controversy over the existence of a reality external to consciousness, and Utpaladeva's main interlocutor at this point of the debate is a Buddhist Sautrāntika. ${ }^{11}$ The latter admits that we can never have direct access to any reality existing beyond consciousness, since the objects of our perceptions are nothing but internal aspects ( $\bar{a} k \bar{a} r a)$ of consciousness; yet he claims that an external reality must be inferred so as to account for phenomenal variety: according to him, consciousness is in itself an undifferentiated manifesting entity or light (prakāśamātra), so that the variety of objects of which we are aware must have a cause outside of consciousness, just as a variety of reflections in a mirror must have as its cause a

11 On the portrayal of this philosophical figure by the Śaiva nondualists and Utpaladeva's refutation of his thesis (both of which are only briefly outlined here), see Ratié 2011, 368402 and 442-473, and Ratié 2011 . 
variety of forms existing outside of the mirror. In İPK 1.5.6, Utpaladeva endeavours to criticize this thesis by showing that the sphere of ordinary human practice (vyavahära) functions on the mere basis of phenomena (so that from this practical point of view, at least, all inquiries into the existence of an external reality are useless) and that further, an external object is not even rationally possible, so that there is no point in assuming the existence of such an absurd object. ${ }^{12}$

In fragment no. 1, Utpaladeva first points out that human activities pertain only to phenomena and that no inquiry over a potential external object is needed to ensure practical success in the everyday world: in the course of ordinary existence we are content to deal with mere manifestations, because these manifestations are endowed with an efficacy (arthakriy $\bar{a}$ ) capable of fulfilling our needs (when we are hungry, we do not ask ourselves whether mangoes exist outside our consciousness: we look for the phenomenon of a mango and are content with experiencing its perceptible effects, since no entity by nature imperceptible can be consumed or utilized).$^{13}$

To this the Sautrāntika could reply that assuming the existence of some imperceptible entities is nonetheless a necessary requirement if we are to make sense of our own perceptions; thus most Indian philosophical systems acknowledge that our eyes, which are perceptible elements of our body, are not enough to explain the phenomenon of vision (since blind people too may possess them), so that we must consider them (as well as our ears, etc.) as mere receptacles for the real sense organs (indriya), understood as instruments of perception that are too subtle to be perceptible, but that must nonetheless be inferred from the fact that we do perceive. Utpaladeva's opponent argues that just as we must assume the existence of the imperceptible indriyas so as to account for our faculty of perceiving, in the same way, we must infer the existence of an external reality so as to explain phenomenal variety. In response to this argument, Utpaladeva points out in the fragment that contrary to what the Sautrāntika claims, the assumption of the indriyas' existence is not universally shared among theoreticians, and in this connection he mentions two theses that claim to explain perception without assuming that such

12 See ĪPK 1.5.6: syād etad avabhāseșu teșv evāvasite sati | vyavahāre kim anyena bāhyenānupapattinā || "Let [us admit] this: since ordinary human practice (vyavahāra) is determined on [the basis of] these manifestations alone, what is the point of some external [object] that would be distinct [from consciousness and] that is not [even] logically possible (anupapatti)?" On the two possible interpretations of syād etat according to Abhinavagupta, see Torella 2002, 114, note 12 , and Ratié 2011,386 , note 48.

13 Cf. İ PV, vol. I, 178, quoted and translated in Ratié 2011, 386. 
imperceptible sense organs must exist. According to Abhinavagupta, one of these theses belongs to Bhartṛhari and was expounded in his now lost Șaddhātusamīkșa, ${ }^{14}$ while the other is that of a "follower of Bṛhaspati" (bārhaspatya), i.e., a materialist (cārvāka). ${ }^{15}$ In fact Utpaladeva disagrees with both theories since in I I PK 1.5.8-9 he clearly admits that the inference of the indriyas is valid; but contrary to the Sautrāntika, he believes that inferring the existence of a purely imperceptible entity is illegitimate and even impossible (which is why he claims that the indriyas are perceived at least in some respect). ${ }^{16}$ Most importantly, it seems that his goal here is merely to show that there is no consensus on the necessity of assuming the indriyas' existence: the fragment only points out that there are competing ways of explaining perception, some of which do not involve the assumption of imperceptible organs of perception, so that the Sautrāntika cannot invoke any universal agreement on the indriyas in order to substantiate the claim that external objects too must be inferred.

Utpaladeva then goes one step further in this first fragment and asserts that the investigation of the external object is not only useless but also doomed to failure, because the external object is not rationally possible.

It is worth noting in this respect that in his commentaries, Abhinavagupta points out that there are two different kinds of argument showing that the external object is impossible from a rational point of view. ${ }^{17}$ The first one simply consists in stating that the external object cannot exist because it cannot be manifest in any way, even as an object of inference. ${ }^{18}$ The second set of arguments (which obviously paraphrases Vasubandhu's Vimsíik $\bar{a}^{19}$ but may have been borrowed, at least in part, from Śankkaranandana's synthetic reformulation of Vasubandhu's arguments in his Prajñälañkāra ${ }^{20}$ ) consists in showing that the external object cannot exist because there is no way of satisfactorily

\footnotetext{
14 On this work see Ratié 2018.

15 See below, notes 88-90.

16 See below, note 115 .

17 See Ratié 2014

18 See ĪPV, vol. I, 178: ... yatra sādhakam ca nāsti pramāṇam bādhakam ca prakāśād bhede 'numeyatayāpi prakāśanābhāva iti tāvan mukhyam. "And there is no argument proving [the existence] of the [external object], and the main (mukhya) [argument] refuting [its existence] amounts to this much: the fact that there [can] be no manifestation (prakāśana) [of it] even as a [mere] object of inference if [this object] is distinct from the manifesting consciousness ( prakāśa)."

19 On the title Viṃśikā (rather than Vimśatikā), see Kano 2008, 345.

20 See ĪPV, vol. I, 181: abhyuccayabādhakam cedam iti nātrāsmābhir bharah krtah. vistareña ca prajñālañkāre darśitam ācāryaśañkaranandanena. "And we have not taken the trouble of [detailing] here what these additional refuting arguments are; and the master Śankaranandana has shown [this] at length in his Prajñälañkära."
} 
explaining it, whether or not we consider it to be made of parts. ${ }^{21}$ Abhinavagupta calls the first argument "principal" (mukhya $)^{22}$ and specifies that while the other, additional arguments focus on the contradictions involved in this or that particular property of the external object, the main argument functions as a global refutation of the external object's existence. ${ }^{23}$ This distinction is not found in Utpaladeva's Vrtti, which merely mentions what Abhinavagupta calls the "additional" arguments, ${ }^{24}$ nonetheless, the İPVv's phrasing shows that it was no innovation on Abhinavagupta's part and that it must have been stated

21 See ĪPV, vol. I, 178: abhyuccayabādhakās tv avayavino vrttyanupapattį̣ samavāāāsiddhị kampākampāvaraṇānāvaraṇaraktāraktadigbhāgabhedādiviruddhadharmayogaḥ ... "As for the additional arguments refuting [the existence of the external object], they are: the impossibility of the existence of a whole (avayavin) [in its parts]; the fact that the inherence (samavāya) [of the whole in its parts] is not established; the fact that the [external object must] possess some contradictory properties, such as movement and the absence of movement, being covered and being uncovered, being colored and being colourless, being differentiated into parts according to [the six] directions (digbhāgabheda), etc." On Abhinavagupta's explanation of these additional arguments and its Buddhist sources see Ratié 2010, 446-452, and Ratié 2011, 390-403.

22 See above, note 18.

23 See İPVV, vol. II, 138: na ca kevalam idam eva bādhakam yat pramānamukhena pravrttam yā̃vat svato 'pītisvamukhena prameyasvarūpanirūpaṇapravrttapratītidvāreṇāpi pravrttam, prameyasvarūpam evāsattvāvișkaraṇenonmūlayaty* eva bāhyam iti yāvat. pūrvakam hi bādhakam prameyasvarūpam anapekșayaiva sāṃśam anaṃśạn viruddham aviruddhaṃ yad bhavatu tad bhavatu, prakāśād bhinnam na prakāśata iti tu sarvagrāsena pravrttam. [ ${ }^{*}$ evāsattvāvișkaranenonmūlayaty conj.; evāsattvāvișkaranaivonmūlayaty T; eva sattvāvișkaraṇenonmūlayaty J10, İ PVV; eva sattāvișkaraṇenomūlyaty J11.] "And [against the thesis of the existence of the external object,] there is not only this [aforementioned] refuting argument (bädhaka) which functions through the means of [valid] knowledge (pramaña) [lacking in the case of the external object]; [there is] also [a refuting argument] which functions 'by itself' [according to the Vivrti], that is to say, through the [external object's] own [nature, or more precisely,] through the awareness arising from the examination of the [contradictory] nature of the object of knowledge (prameya). [The latter argument] completely eradicates the very nature of the object of knowledge-that is to say, the external [object] — by showing that [this contradictory nature can]not exist. For the first refuting argument functions while completely disregarding the nature of the object of knowledge-[i.e.] whether it has parts or is devoid of parts, whether it is contradicted or not [by this or that particular property] —rather, [it functions] through a global refutation (sarvagrāsena [lit. 'by devouring everything']), thus: '[What is] distinct from the manifesting consciousness (prakāśa) is not manifest (na prakāśate)."

24 See Vrtti on İPK 1.5.6, 20-21: ... bāhyaś cārthah pramānabādhitaḥ sāvayavo viruddhadharmādhyāsāder niravayavaś ca dikșațkayogāder bahuśah. "Moreover, [the existence of] the external object is refuted by a means of [valid] knowledge if it has parts, because of [the necessity then] of attributing to it contradictory properties, etc.; [and it is contradicted] in many ways if it has no parts, because [then] it must be in contact with the six directions, etc." 
by Utpaladeva himself in his Vivrti. ${ }^{25}$ This is confirmed by the fragments presented below. While fragment no. 3-which mentions the famous criticism of atomism in Vasubandhu's Vimssikā 11-15-is obviously concerned with the second set of arguments, ${ }^{26}$ in fragments no. 1 and 3 Utpaladeva clearly refers to the first, "principal" argument against the existence of the external object; thus the end of fragment no. 1 explains that the only possible objects for consciousness are phenomena and that objects are nothing but the manifesting consciousness ( prakāśa), and fragment no. 2 further explains that even objects known through inference must be manifested (avabhäta) in some way so as to be objects for consciousness.

This latter point is crucial, because the idea that even conceptual objects must be directly manifested in some way is one of the main divergences between Buddhist and Śaiva nondualistic epistemologies, as Abhinavagupta himself makes clear in his commentary. ${ }^{27}$ The Śaiva nondualists thus accuse the Vijñānavādins of unwittingly granting some legitimacy to the externalism of their Sautrāntika opponents by admitting that contrary to a perceived object, the object of a mere concept does not require any immediate manifestation at the time of its conceptualization. According to the Saivas, such a concession entails that there is nothing inherently wrong in trying to infer, as the Sautrāntikas do, an external object by nature alien to manifestation, whereas Utpaladeva and Abhinavagupta deny the mere possibility of even conceptualizing — and therefore inferring — an entity fundamentally distinct from consciousness. ${ }^{28}$

At the end of fragment no. 2, Utpaladeva states a new objection on the part of his externalist opponent. According to the Sautrāntika, if we do not assume the existence of an external reality, we cannot explain why we are aware of a phenomenal variety that occurs in a specific sequence: there must be a reason for the fact that some things are manifest to us and that these manifestations occur successively rather than simultaneously. As Abhinavagupta puts it, "a manifestation necessarily requires a cause as regards both [its] arising and [its] not arising, ${ }^{29}$ and if we do not attempt to determine that cause, the very notion of causality as well as that of the relationship between the apprehending subject and the apprehended object (which, according to the Buddhists, depends

25 See I IPVV, vol. II, 138, quoted above, note 23.

26 For an explanation of Abhinavagupta's commentaries on this point see Ratié 2010, 451$45^{2}$ and Ratié 2011, 395-399.

27 See below, note 94 .

28 On this divergence see Ratié 2011b, 496-498.

29 See below, note 99. 
on the causality relationship) is lost. The Sautrāntika's intention is obviously to have his opponent admit that the only possible cause for this phenomenal variety endowed with a specific order is a variety of external objects possessed of a corresponding specific order and projecting their forms onto consciousness.

Unfortunately, Utpaladeva's answer to this objection is not to be found in the margins of the manuscripts that I have consulted so far. It is possible, however, to retrieve the gist of Utpaladeva's reply from Abhinavagupta's İPVV: Utpaladeva seems to have argued in the missing passage of the Vivrti that the Sautrāntika cannot rightfully look for an external cause explaining the arising of manifestations as well as their lack of arising, because reality (understood as a unique and all-encompassing consciousness) is always manifest and always evident for any conscious entity, in the form of the immediate self-awareness inherent in any subjectivity. ${ }^{30}$ In fact temporal and spatial sequences (käladeśakrama) are nothing but ways for consciousness to manifest its unitary nature as if it were differentiated, and this differentiated manifestation is the result of the fundamental dynamism of consciousness, conceived as a constantly exerted power of manifesting itself in all possible forms. Thus according to the Śaiva nondualists, consciousness is not a mirror passively reflecting a world of objects existing independently of it, and phenomenal variety, far from being the mere reflection of such an external world, is an expression of consciousness's freedom (svātantrya) to manifest itself in an infinite variety of forms while playfully hiding its fundamental unity. The Sautrāntika is therefore wrong to assume that phenomenal variety and its spatio-temporal sequence can only be explained by postulating an external cause, since they can be accounted for as the result of the freedom of consciousness ${ }^{31}$ - a free-

30 See e.g. İPVV, vol. II, 133: paramabhūmir āgameșu paramarahasyāpi satī naivānābhāsamānā bhavaty api tv ābhāsamānaiveti tātparyam. etad ādisiddhasūtre ca vyākhyātam. "The highest level [of reality], although it is concealed to the highest point within the [Śaiva nondualistic] scriptures, is absolutely never unmanifest; rather, it is always [in the process of] manifesting [itself] — this is the gist [of Utpaladeva's answer]. And [Utpaladeva] has explained this in the verse on [the Self being] always already established." The verse to which Abhinavagupta is alluding here is ĪPK 1.1.2: kartari jñātari svātmany ãdisiddhe

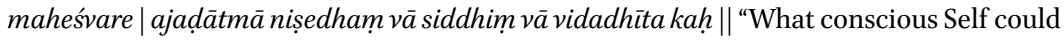
produce either a refutation or a demonstration [of the existence] of the agent, the knowing subject, the always already established (ädisiddha) Self, the Great Lord?"

31 On the attempt in the Pratyabhijñā treatise to eliminate all rival explanations for phenomenal variety (i.e. that of the Sautrāntikas, but also that of the Vijñānavādins, who account for phenomenal variety by invoking an internal mechanism of latent traces or imprints, $v \bar{a} s a n \bar{a}$ ) in order to show that the freedom of consciousness is the only possible cause for it, see e.g. İPV, vol. I, 163-164 (quoted and translated in Ratié 2011, 367-368); see also ĪPV, vol. I, 184-185, and ĪPVV, vol. II, 8o-81 (quoted and translated in Ratié 2010, 461-464). 
dom which, contrary to an external object, is experienced by all conscious beings, for example when they imagine. ${ }^{32}$

\section{The Context and Gist of Fragments 4-6? on İPK 1.5.8-9}

In İPK 1.5.8-9, ${ }^{33}$ Utpaladeva comes back to the Sautrāntika's contention that the external object can and must be inferred, and he endeavours to show that this inference is simply impossible. In fragment no. 4, he first argues that inferential knowledge is conceptual in nature and that the concept in which the inference results arises thanks to the residual trace (samskāra) left by a previous experience. When we draw from the fact that a distant hill is smoky the conclusion that there must be a fire there, our concept of fire arises thanks to our previous experiences of fire and smoke; fire can be a conceptual object for us only because we have already witnessed fires in the past, and these previous experiences of fire have left in the conscious stream a trace that is reactivated when we form the inferential concept of "fire." It is this residual trace that guarantees the possibility for the conceptual object to be an object manifest for consciousness, as well as the reliability of concepts as tools in the sphere of human practice, because it enables an object directly perceived in the past but no longer existing to be manifested again.

The consequence of this remark is that the external object cannot be inferred precisely because it is by nature imperceptible: it has never been manifest to any consciousness (if it had, it would not be external) so that we cannot form any concept of it. ${ }^{34}$ Utpaladeva also points out that an inference is valid insofar as it manifests the conceptual object as particularized by a specific time and place rather than as a pure abstraction: our knowledge that a hill is on fire

32 See Ratié 2o1ob.

33 anumānam anābhātapūrve naiveșțam indriyam | ābhātam eva büjāder ābhāsād dhetuvastunạ̣ || ābhāsaḥ punar ābhāsād bāhyasyāsīt kathaṃcana | arthasya naiva tenāsya siddhir nāpy anumānatah || "No inference can be admitted as regards that which has never been manifested previously. [Before being inferred,] a sense organ has already been manifested [at least in the general form of a cause] through the manifestation of a real entity that [happens to be] a cause, such as a seed [which is the cause of a sprout]; but the manifestation of an object external to manifestation has never occurred in any way. Therefore there can be no establishment of this [external object]—not even through an inference." Cf. İ PVV, vol. II, 161: tad anupapannam saṃvidbāhyasya svapne 'py anābhātasya vikalpyatvāyogād anumeyatānupapannā yatah. "This [inference of an object particularized by its being external to consciousness] is impossible, since [an entity] external to consciousness - [and therefore] unmanifested, even in a dream - cannot be an object of inference, because [such an entity] cannot be the object of a concept." 
because it is smoky would be useless if it were not the knowledge that the particular hill currently seen is on fire - an idea shared with the Dharmakīrtians, particularly Dharmottara ${ }^{35}$ (who might be targeted, here as in Abhinavagupta's ĪPVV, as the Sautrāntikas' most prominent champion). ${ }^{36}$ Here too, Utpaladeva does not explicitly draw the consequence of this affirmation, but his aim is probably to show that the external object cannot be inferred because, as he emphasizes later in the treatise, spatial and temporal relations, which are nothing but a partial incompatibility between some determined phenomena, can only belong to manifest entities, ${ }^{37}$ whereas the external object must remain purely indeterminate as regards form, time and space.

To this argument the Sautrāntika could object-and obviously did in a now missing passage of the Vivrti-that some inferences do not rest on a previous perception and actually regard an entity that is by nature imperceptible. According to Abhinavagupta's commentaries, here Utpaladeva's opponent relies on the traditional distinction between the pratyakșatodrsț and sāmannyatodrșta types of inference, ${ }^{38}$ and he argues that in the case of the sense organs, the indriyas are not inferred as some particular entity directly witnessed in the past, but as a mere generality (sāmānya), i.e. as a "mere something" (kiñcinmātra) that must be assumed as a purely indeterminate cause of perception. This enables the Sautrāntika to claim that the external object can be inferred as the cause in general of phenomenal variety, although just as the sense organs, it has never been perceived. ${ }^{39}$

Fragment no. 5 is a response to the Sautrāntika's objection. Utpaladeva claims that the reason why we can infer the sense organs as a mere indeterminate cause of perception is that in fact the sense organs have already been perceived, at least in the general form of a cause. Utpaladeva can afford to defend this paradoxical thesis because he has already shown that the perception of any particular entity is in fact the synthetic apprehension of a number of elementary phenomena ( $\bar{a} b h \bar{a} s a)$ that, when put together, constitute the singularity of the perceived entity, but that, when taken separately, function as generalities (sāmānya).$^{40}$ This means that according to him, the generality "causality" is in fact directly perceived in all our experiences of entities endowed with a causal

\footnotetext{
35 See Torella 2002,117 , note 19.

36 On the probability that Abhinavagupta at least saw Dharmottara as defending the Sautrāntika position, see McCrea and Patil 2010, 141-142, note 71, and McCrea 2016.

37 See below, note 111.

38 See below, note 113 .

39 On Abhinavagupta's explanation of this objection see Ratié 2011b, 486-488.

40 See below, note 115 .
} 
power (for instance, in our perception of a seed capable of producing a sprout, or in that of clay as the material cause of a pot). ${ }^{41}$

Of course, Utpaladeva's strategy here might seem very risky, since the Sautrāntika could argue that just as the sense organs are inferred as a mere general cause enabling us to account for the phenomenon of perception (a general cause already perceived in countless previous experiences of particular causes), in the same way, the external object can be inferred as a mere generality, given that the generality "externality" is constantly experienced in the course of everyday life: we can draw the concept of an object external to consciousness from our past experiences of objects external to houses, villages, mirrors, etc. If Utpaladeva concedes that the sense organs have already been perceived as a general cause and can legitimately be inferred as such, he should accept the same kind of reasoning regarding the external object inferred as a mere "external thing" in general. This objection is the content of fragment no. 6 ?. As explained below, ${ }^{42} \mathrm{I}$ am not sure whether this last passage really is a fragment of the Vivrti; but if it is not, it must at least be a paraphrase of it, because Abhinavagupta's $\overline{\mathrm{I}} \mathrm{PVV}^{43}$ shows that Utpaladeva had expressed this very objection in the Vivrti.

Unfortunately, once more Utpaladeva's answer to this objection is missing from the margins of the manuscripts that I was able to consult; but here too, the gist of his answer is preserved in Abhinavagupta's commentaries on I PK 1.5.9. ${ }^{44}$ Utpaladeva apparently argued first that in the case of the sense organs, what is inferred as a cause is a mere generality, whereas in the case of the external object, the Sautrāntika tries to infer a cause that is not a mere generality since it is particularized by the peculiar property of being external to consciousness. Now, contrary to the notion of causality, this property cannot have been included in any previous perception; indeed, we do perceive entities that are external to other entities, but the case of an entity external to consciousness is radically different from that of the pot being external to a house or a mirror, because in the latter examples externality only means a spatial relationship of proximity between two forms occupying a particular place, whereas when the Sautrāntika talks about an object external to conscious manifestations, he does not have in mind an object that would stand next to consciousness (since consciousness is not spatially determined): he rather means an object that is not

41 As noted by Torella (2002, 116, note 18), Utpaladeva thus "include[s] the concept of sāmānyatodrșța within the pratyakșatodrșta."

42 See note 79 .

43 See below, note 119.

44 See Ratié 2011b, 491-498 and below, note 119. 
consciousness. Such an object cannot be conceptualized on the basis of our former perceptions involving externality, since there is only a "verbal similarity" (śabdasāmya) between the externality (i.e. proximity) of a pot with respect to a house, and the externality (i.e. absolute otherness) of an object with respect to consciousness. And the latter type of externality constitutes the very limit of our power of conceptualization, since however wild our imagination may be, we are incapable of picturing anything that would be by nature alien to conscious manifestation. This experience of our limitation as conscious beings is paradoxically what reveals the infinite power of consciousness: the very notion of a reality existing beyond consciousness is unthinkable and therefore absurd, and according to the Śaiva nondualists, this means that whatever exists only exists as a manifestation of consciousness.

\section{$4 \quad$ Fragments of Utpaladeva's Vivrti on İPK 1.5.6}

The words quoted in Abhinavagupta's İPVV are in bold type. I have taken the liberty of adding punctuation marks and standardizing sandhi. The margins of $\mathrm{S}_{3}$ are often damaged and difficult to read; illegible akșaras are noted below with the sign "[?]." The İPVV quotations given in footnotes below only mention readings found in the three consulted İPVV manuscripts when the text of the KSTS edition seems likely to be corrupt.

[1] ${ }^{45}$ vyavahartrapekșayā tāvad bhāvavyavasthā kriyamāṇāvabhāseṣv eva nirapāya $\bar{a}$ paryavasyatīty adhikatarādrșțavastuparyālocanam idam svacchandaceșțitam. yathaiva ${ }^{46}$ hindriyavicāram vinā na na kiñcid upapadyate ${ }^{47}$ tathā

45 This passage is found in $\mathrm{S}_{3}$ (where it begins on the top margin of folio $40 \mathrm{OB}$ ), $\mathrm{S}_{15}$ (top margin of folio $47 \mathrm{~A}$ ), $\mathrm{J}^{\mathrm{R}}$ (folio $82 \mathrm{~B}$, top margin) and (up to the quotations mentioned below in note 51 ) I PV, vol. I, 176-177, note 17O. It does not appear in $\mathrm{D}_{2}, \mathrm{~S}_{2}, \mathrm{~S}_{5}, \mathrm{~S}_{7}$, S9 or soAs, but it is found in I $\mathrm{PVV}$ manuscript $\mathrm{S} 12$ (folio 121B, right and bottom margins).

46 yathaiva ] conj.; yathā $\mathrm{S}_{3}, \mathrm{~S}_{15}, \mathrm{~J}^{\mathrm{R}}$, note $170 \mathrm{I} \mathrm{PV}$ (vol. I, 176). Cf. Ī PVV, vol. II, 131: yathaivety asya tathaivety anena sambandhah.

47 na na kiñcid upapadyate ] conj.; na kiñcid upapadyate $\mathrm{S}_{3}, \mathrm{~S}_{15}, \mathrm{~J}^{\mathrm{R}}$, S12, note $170 \mathrm{I} \mathrm{PV}$ (vol. I, 176). The conjecture is of course tentative but I cannot understand the text as it stands. Vincent Eltschinger and Eli Franco both suggested eliminating the negation as a corruption instead of doubling it, and they might be right. However, I personally find the double negation more in accordance with the writing habits of Utpaladeva and Abhinavagupta (I am assuming that the former shared with the latter a propensity for double negations). For his part Eli Franco considers that "nobody writes like this" and that "if a second negation should be added, one would expect it in the beginning (yathā na hi ...)." (Personal written communication.) However, there is no doubt that at least Abhinavagupta writes 
hi kecid indriyāpavarjanenaiva șaḍdhātuvādinaḥ, anye taddvayavādina iti tathaiva pratibhāsātiriktātyantaparokșārthānveșaṇam antarenaiva vyavahāraparisamāptir ity anañgam tadvicārah.

nāpi vicārasiddhatvam ${ }^{48}$ asya $^{49}$ bähyasyānupapatter ity āha syād etad ity evam cābhāsānām evārthatve prakāso 'rthah, artho 'pi ca prakāśa iti parasparātmakatvam ${ }^{50}$ anayor bhavati.

$[\ldots]^{51}$

like this (i.e. by simply juxtaposing two negations, whether the sentence comprises subordinate clauses or not), and in fact such occurrences of na na are quite often found in his works, not only in those which are not directly related to the Pratyabhijñā (see e.g. Tantrāloka 9.251cd and 12.5a; Parātrišíikāvivaraṇa, 19o, line 11; Mālinišllokavārttika 1.123ab, etc.) but also in the İPV (see e.g. vol. I, 216, line 5, or vol. II, 33, last line), and they are particularly numerous in the İPVV (see vol. I, 36 , line 21; 38, line 16; 6o, line 12; 109, line 17; 181, line 12; 287, line 17; 296, line 11; vol. II, 6, line 5; 57, line 22; 82, line 3; 325, line 6; 332, line 9; 334, line 5; 344, line 7; 347, line 11; 35o, line 16; 357, line 12; 415, line 23; 436, line 21; vol. III, 34, line 19; 66, line 13; 107, line 12 and line 20; 218, line 6; 301, line 3; 344, line 9; 366, line $12 ; 369$, line $7 ; 382$, line 24$)$. These double negations often occur with verbs the meaning of which is close to upapad- (such as yujyate/yuktam, vaktum śakyate, etc.) and both the expressions na nopapadyate and na nopapannā are found in the İPVV (see vol. II, 334, line 5 and 357 , line 12 ).

48 vicārasiddhatvam ] S3, S15, J ${ }^{\mathrm{R}}$, S12; vicārasiddham note $170 \mathrm{I} \mathrm{PV}$ (vol. I, 176).

49 asya ] conj.; api $\mathrm{S}_{3}, \mathrm{~S}_{15}, \mathrm{~J}^{\mathrm{R}}$, S12, note $170 \mathrm{I} \mathrm{PV}$ (vol. I, 176).

50 parasparātmakatvam ] S3, S12, note $170 \mathrm{I} \mathrm{PV}$ (vol. I, 176); parasparātmatvam $\mathrm{S}_{15}, \mathrm{~J}^{\mathrm{R}}$. There is a discrepancy here between the text of the Vivrti as found in the marginal annotations (parasparātmakatvam) and Abhinavagupta's pratīka in the ĪPVV (pratītiparamparātmaketi). Abhinavagupta's explanation, however, seems to require rather parasparātmaketi since it makes no mention of a series or succession (paramparā) of cognitions (pratiti) and explains that ultimately the vyavahära requires the identity of the object with the manifesting consciousness (see below, note 92), which fits with the text given in the marginal annotations. So I assume that parasparätmaketi first got corrupted into paramparātmaketi and that someone then added pratīti $i^{\circ}$ to try and make sense of this "succession," but I might be entirely wrong (this pratika might in fact belong to a passage of the Vivrti that is missing in the marginal annotations; see the following note).

$5^{1}$ At this point the marginal annotations in $\mathrm{S}_{3}, \mathrm{~S}_{15}, \mathrm{~J}^{\mathrm{R}}$ and $\mathrm{S}_{12}$, as well as note 170 in ĪPV, vol. I, 176-177, give a series of quotations that do not seem to belong to the Vivrti itself (?). The İPVV, which makes no mention of these quotations, comments on a hi and a tat not found in the annotations: ity abhipretyoktam gìtāsu* yo mām paśyati sarvatra sarvam ca mayi* paśyatīti tathā sarvabhūtastham àtmānam sarvabhütāni cātmanìti tathā mahägurubhir* ätmaiva sarvabhāveșu sphuran nirvrtacidvibhuh $\mid$ aniruddhecchāprasarah

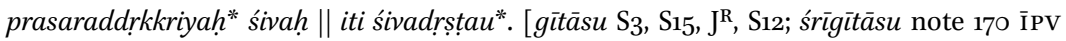
(vol. I, 176). *mayi $\mathrm{S}_{3}$, J', S12, note $17 \mathrm{O}$ I PV (vol. I, 176); maya $\mathrm{S}_{15} .{ }^{*}$ mahägurubhir $\mathrm{S}_{3}$, S15, $\mathrm{J}^{\mathrm{R}}$, S12; mahāgurubhị̣ śivadrșțau note $17 \mathrm{O}$ I PV (vol. I, 177). ${ }^{*}$ kriyah S S3, J ${ }^{\mathrm{R}}$, S12, note $170 \mathrm{I}$ PV (vol. I, 177); ${ }^{\circ}$ kriyā S15. *iti śivadrșțau S3, S15, J ${ }^{\mathrm{R}}, \mathrm{S} 12$; iti note $170 \mathrm{I} \mathrm{IPV}$ (vol. I, 177).] "It is with this [very] intention that it has been said in [Bhagavad-] gita a [6.30]: 'He who sees me and sees everything in all circumstances in me ...'; and similarly, [in 6.29,] '[He sees] himself 
[2] ${ }^{52}$ yo 'py ānumāniko vyavahāraḥ so 'py avabhāsamānenaiva vahninā, vikalpapratyaye 'py avabhāto bāhya eva vahnir avasīyate. tata eva bāhya eva pravrttir vahnāv eva ca pravrttih̆, atīndriyenāpīndriyādinā svargāpavargādinārthena ${ }^{53}$ vikalpapratibhāsinaiva ${ }^{54}$ vyavahāraḥ. evam cābhāsamānarūpataivārthatā tāvanmātra eva ca prayojanam.

[as] residing in all entities and all entities [as residing] in himself'; [and] similarly, the great master [Somānanda has said] in Śivadrșți [1.2]: 'Śiva, who is [constantly] engaged in flashing forth, whose consciousness is blissful, who is all-pervading, whose flow of will is not obstructed [by anything], [and] whose perception and action are [constantly] flowing, is none other than the Self of all entities.'” $S_{3}$ then gives the Vrtti (bottom left margin) followed by what seems to be the Vivrti again; in $\mathrm{J}^{\mathrm{R}}$ this passage, in the right margin, is clearly separated from the Vrtti, which is copied at the bottom of the page (and indicated as such at the end: iti vrttih), and immediately followed by the same passage apparently taken from the Vivrti. The same happens in $\mathrm{S}_{15}$ (where the Vrtti and the remainder of the annotation are found in the left margin). Note that note 6 of the Sivadrsți edition, 4, which is apparently borrowed from a marginal annotation in manuscript $\mathrm{D}_{3}$ (the latter being in all probability the manuscript "a" used by the KsTs editors), gives the same quotations from the Bhagavadgit $\bar{a}$ while commenting on this verse, and introduces them with a text almost identical to that found here: evam cārthasya prakāśatve prakāso 'py arthah, artho 'pi prakāsah. "And [since it is] so, since the object is the manifesting consciousness, the manifesting consciousness is the object, and conversely the object is the manifesting consciousness." My assumption that the Sivadrșți manuscript called "a" by the KSTS editors is none other than $\mathrm{D}_{3}$ is based on the fact that the description of "a" (Śivadrsți, I-II) closely corresponds to $D_{3}$ (which unfortunately I was only able to examine very quickly at the National Archives of India) as regards the number of folios, the average number of lines per folio, and the average number of akșaras per line, not to mention that both manuscripts bear many marginal annotations (at least some of which are identical). Both, moreover, are bound together with manuscripts of the İPV, Parätrissika and Paramādvayadvādaśikā. It should also be noted that another Śivadrșți manuscript originally owned by the Śrinagar Research Library is now preserved in the National Archives of India (D4); I could not consult it as it had been sent for repair at the time of my visit to the Archives, but from the catalogue description I suspect that it might be the Devanāgarī transcript called "b" by the KsTs editors. A thorough analysis of $\mathrm{D}_{3}$ and $\mathrm{D}_{4}$ would therefore certainly be a welcome addition to the examination of some Śivadrsți manuscripts provided in Nemec 2011, 79-9o.

$5^{2}$ This passage occurs in $\mathrm{S}_{3}$, folio $4 \mathrm{OB}$ (third line from the bottom of the page), $\mathrm{S}_{15}$, folio $47 \mathrm{~A}$ (left margin) and $\mathrm{J}^{\mathrm{R}}$, folio $82 \mathrm{~B}$ (bottom margin, from line 2 onwards, then on the right margin). It is not found in $\mathrm{D}_{2}, \mathrm{~S}_{2}, \mathrm{~S}_{5}, \mathrm{~S}_{9}, \mathrm{~S}_{10}$, soAS or in the footnotes of the KSTS edition of the ĪPV, but it also occurs in the I IPVV manuscript S12 (folio 121A, bottom margin).

svargāpavargādinārthena ] conj.; svargāpavargādinā nārthena $\mathrm{S}_{3}, \mathrm{~S}_{15}, \mathrm{~J}^{\mathrm{R}}$; sargāpavargāadinā nārthena S12. Cf. ĪPVV, vol. II, 132, quoted below, note 95 .

$54 \mathrm{~S}_{3}, \mathrm{~S}_{15}, \mathrm{~J}^{\mathrm{R}}$ and $\mathrm{S}_{12}$ all bear this reading, and although the pratīka in $\overline{\mathrm{I}} \mathrm{PVV}$, vol. II, 132 is given as vikalpapratibhāsiteti, at least one Ī PVV manuscript has vikalpapratibhāsineti (see below, note 95). 
sā tv ābhāsāt prthagbhūtānām eveti ko yam graha ābhāsaikatvena kā vyavahārakhaṇdanā, tad āha te cābhāsātmakāh santv iti.

kevalam ürdhvam äbhäsamānatāyāḥ pūrvam ca $\boldsymbol{c a}^{55}$ yadi te na syus tadābhāsamānataivākasmikī, ${ }^{56}$ kāryakāraṇabhāvo jñāpyajñāpakabhāvaś ca nopapadyata ${ }^{57}$ iti paryanuyojyam.

$[\ldots]$

$[3]^{58}$ atha bāhyārthāḥ ${ }^{59}$ paramānava eva niravayavāḥ sañcitās tathāpi ghațo vitatarūpatvena prathamānah pūrvāparādibhāgavān eva prathate, na caivam paramānumayatve ghațate. tathā hi yo 'sau pūrväbhimatah paramānuus tena dvitīyah paramāṇuh saṃśliștamānas tadekatām āpadyeta ${ }^{60}$ niravayavayor hi saṃlagnatve kiyad asạ̣lagnam avaśisyate, saṃlagnau cānyonyasvarūpaparimagnāv ity ekaparamāṇvābhāsataiva, ${ }^{61}$ punar apy aparaparamāṇusaṃsparśe $e^{62}$ tathaivety anantaparamāṇuyojane 'py ekaparamāṇumātraprakāśaḥ ${ }^{63}$ syāt, so 'pi vā na syād ekaikaparamānor ${ }^{64}$ atīndriyatvāt. ${ }^{65}$

$55 \quad$ ca S$_{3}, \mathrm{~J}^{\mathrm{R}}$, S12; om. $\mathrm{S}_{15}$.

56 tadābhāsamānataivākasmikī ] S15, J ${ }^{\mathrm{R}}, \mathrm{S}_{12}$; tadā[?]samānataivākasmikī $\mathrm{S}_{3}$.

57 ca nopapadyata ] conj.; copapadyata $\mathrm{S}_{3}, \mathrm{~S}_{15}, \mathrm{~J}^{\mathrm{R}}, \mathrm{S}_{12}$.

$5^{8}$ This passage is again found in $\mathrm{S}_{3}$ (folio $41 \mathrm{~A}$, top margin, from line 3 , continuing on the left margin), $\mathrm{S}_{15}$ (from folio $47 \mathrm{~B}$, bottom margin, to folio $48 \mathrm{~A}$, top margin), $\mathrm{J}^{\mathrm{R}}$ (folio $8{ }_{3} \mathrm{~B}$, bottom margin, immediately after a quotation from the İPVV corresponding to vol. II, 141, and folio $84 \mathrm{~A}$, top margin) and S12 (folio $124 \mathrm{~B}$, top margin). In all of these manuscripts it is preceded by etad evāha svavrttivivrtigranthakāra utpalācāryah (S12 has tad äha instead of etad evāha). It is also found in D2 (folio 108B, right margin), SOAs (folio 10oB, top margin) and note 192 in İ $\mathrm{PV}$, vol. I, 180, in all three cases from ghațo vitatarūpatvena prathamānah ... (with a hi inserted after ghațo) to atīndriyatvāt. I could not find it in $\mathrm{S}_{2}, \mathrm{~S}_{5}, \mathrm{~S}_{7}$ and $\mathrm{S}_{9}$.

59 bāhyārthāh ] conj.; bāhya .. $\mathrm{S}_{3}, \mathrm{~S}_{15}, \mathrm{~J}^{\mathrm{R}}, \mathrm{S}_{12}$.

6o āpadyeta ] $\mathrm{S}_{3}, \mathrm{~J}^{\mathrm{R}}, \mathrm{D} 2$, S12; āpadyete soAs; āpadyate note $192 \mathrm{I} \mathrm{IPV}$ (vol. I, 180). It is impossible to decide whether $\mathrm{S}_{15}$ reads āpadyeta or äpadyate.

61 ekaparamāṇvābhāsataiva ] S3, S15, J ${ }^{\mathrm{R}}, \mathrm{D} 2, \mathrm{~S} 12$; ekaparamāṇur bhāsetaiva soAs, note 192 İPV (vol. I, 180).

62 aparaparamāṇusaṃsparśe ] $\mathrm{S}_{3}, \mathrm{~S}_{15}, \mathrm{~J}^{\mathrm{R}}, \mathrm{D} 2, \mathrm{~S} 12$; aparaparimāṇusaṃsparśe soAs; aparaparamāṇusaṃsparśo note $192 \mathrm{I} \mathrm{I} P V($ vol. I, 180).

63 ekaparamāṇumātraprakāśah ] S3, S15, J ${ }^{\mathrm{R}}$, D2, S12, note 192 ĪPV (vol. I, 180); ekaparimāṇumātraprakāśạ soAs.

64 ekaikaparamānoror ] $\mathrm{S}_{3}, \mathrm{~S}_{15}, \mathrm{~J}^{\mathrm{R}}, \mathrm{D} 2, \mathrm{~S} 12$, note 192 İ PV (vol. I, 180); ekaikaparimānọor soAS.

65 From this point onwards, the marginal annotations in $\mathrm{S}_{3}, \mathrm{~S}_{15}, \mathrm{~J}^{\mathrm{R}}$ and $\mathrm{S}_{12}$ quote $\overline{\mathrm{I}} \mathrm{PVV}$, vol. II, 141 (evam kramasaṃśleșe doșaḥ, etc.) without mentioning this change (but the sentence has been put in what looks like parentheses in S12). The annotation on the right margin in $\mathrm{S}_{3}$ is also taken from the ĪPVV (see vol. II, 142: șațkone devanākșādau, etc.). 


\section{$5 \quad$ Fragments of Utpaladeva's Vivrti on ĪPK 1.5.8-9}

[4] ${ }^{66}$ anumānam hi vikalpaḥ, sa ca pūrvānubhavasamskārasamuttha iti tāvad arthasya pūrvapratyakșatāpekșa ${ }^{67}$ tasmiṃś cārthe vikalpapratītir avyabhicārajanitānumānam, ${ }^{68}$ tac cānubhavasamskārād antahsthitatadartham idantaucityena yāvad vimrsśati tāvad vicchedena prathayati. na ca tāvatā pravrrttivișayo 'sāv arthaḥ, tena prakāśito bhavati viśiștadeśakālo viśiștadeśakālasyaiva svalakșaṇasya ${ }^{69}$ prāpyatvenābhișțārthakriyākāritvena ${ }^{70}$ ca pravrttivișayatāyogyatvād ${ }^{71}$ atas tathaiva yad vimarśanam, tad āha pūrvāvabhāteti ${ }^{72}$ nāntarīyakārtheti ${ }^{73}$ tattaddeśakālādīti. ${ }^{74}$

$[\ldots]^{75}$

$[5]^{76}$ indriyam api pūrvānubhūtam eva, na hi tat prātisvikenākāreṇānumìyate, api tu sāmānyena, tad āha vrttau kiñcinmātram nimittam iti. ayam artho nimittatāsāmānyam, pūrvapratibhātam eva büjasyāìkuranimittatājñāne

66 This fragment appears in marginal annotations in $\mathrm{S}_{3}$ (top of folio $43 \mathrm{~A}$, line 1 , after a quotation from the İPVV, then on the right margin-see figure 5.1), $\mathrm{S}_{15}$ (folio $5 \mathrm{OA}$, top and left margins), JR (folio $87 \mathrm{~B}$, right margin) and S12 (folio 130A, left and bottom margins); I could not find it in $\mathrm{D}_{2}, \mathrm{~S}_{2}, \mathrm{~S}_{5}, \mathrm{~S}_{7}$, $\mathrm{S}_{9}$ and soAs.

67 pūrvapratyakșatāpekșā ] S3, J ${ }^{\mathrm{R}}, \mathrm{S}_{12} ;$ pūrvapratyatāpekșā $\mathrm{S}_{15}$.

68 I assume that the reading avyabhicāritti in ĪPVV, vol. II, 161 is a corruption for avyabhicāreti (see below, note 108).

69 viśiștadeśakālo viśișțadeśakālasyaiva svalakșaṇasya ] conj.; viśiștakālasyaiva svalakșaṇasya $\mathrm{S}_{15}$, J ${ }^{\mathrm{R}}$; viśișțadeśakālasvalakșaṇasya $\mathrm{S}_{12}$; vi[??]deśakāla[?]svalakșa[?]sya $\mathrm{S}_{3}$. This is merely tentative, but from the meaning of the passage as it is summed up by Abhinavagupta (see below, note 110), I assume that something is missing in the text of the manuscripts.

70 prāpyatvenābhīștārthakriyākāritvena ] $\mathrm{S}_{15}, \mathrm{~J}^{\mathrm{R}}, \mathrm{S} 12$; prāpya[?]nābhișțārthakriyākāa [?]tvena $\mathrm{S}_{3}$.

71 pravrttivișayatāyogyatvād ] $\mathrm{S}_{15}, \mathrm{~J}^{\mathrm{R}}$, S12; pravrttivișayatāyo[?]tvād $\mathrm{S}_{3}$.

72 pūrvāvabhāteti] $\mathrm{S}_{15}, \mathrm{~J}^{\mathrm{R}}, \mathrm{S}_{12} ;$ pūrvāva[?]teti $\mathrm{S}_{3}$.

73 nāntarīyakārtheti $] \mathrm{S}_{15}, \mathrm{~J}^{\mathrm{R}}$, S12; nāntarīya[?]rtheti $\mathrm{S}_{3}$.

74 tattaddeśakālādīti ] corr.; taddeśakālād iti $\mathrm{S}_{15}, \mathrm{~J}^{\mathrm{R}}$, S12; taddeśakālād[?] S3. Cf. Vrtti, 21-22, quoted below, note 111 .

75 Here a part of the text is missing, as is obvious from Abhinavagupta's commentary (ĪPVV, vol. II, 162), which mentions the words eșa punar and vyāptivimarśät, and again (ĪPVV, vol. II, 163) dharmapratyakșa. The next fragment is commented in İPVV, vol. II, 163.

$7_{6}$ The following fragment appears in marginal annotations in $\mathrm{S}_{3}$ (folio $43 \mathrm{~A}$, right marginsee figure 5.1), S15 (folio 50A, left margin), JR (folio 87B, right margin) and S12 (folio 130A, bottom margin), in all cases immediately after the preceding Vivrti fragment. The first sentence up to sämānyena is also found in note 236 in İPV, vol. I, 188, but I could not find it in $\mathrm{D}_{2}, \mathrm{~S}_{2}, \mathrm{~S}_{5}, \mathrm{~S}_{7}$, S9 and SOAS. 
mrrdāder ghațādinimittatājñāne. ${ }^{77}$ na hi tatra viśișțạ̣ bïjam eva nimittatvena pratibhātam, mrịo 'py ajñānaprasañgāt. nāpy uttaratra mṛd eva bïjāder ajñānaprasañgāt. prasaktataditaravyavacchedāyaiva viśeșaṇam prayujyate cātrāpi, mṛd eva kāraṇaṃ ghațasya ${ }^{78}$ na bïjam iti.

$[\ldots]$

[6] ${ }^{? 79}$ nanu $^{80}$ cakșurādiviśeșaparihārena yathā büjādyanubhavāt ${ }^{81}$ kāraṇatāsāmānyam ${ }^{82}$ anubhūtam evoktam, tathā śarīrād grhād grāmāder vā bāhyasyānubhavād bāhyatvam api sāmānyenānubhūtam evājñānaviśeșeṇa ${ }^{83}$ bāhyatvānanubhavoktau vā cakșurāder api kāraṇaviśeșasyānanubhūtapūrvatvān na syād anumānaṃ tat kathaṃ nānumānasya vyāpāra ${ }^{84}$ ity uktị.

\section{$6 \quad$ Translation of the Fragments on İPK 1.5.6}

[1] To begin with, as far as agents of ordinary human practice (vyavahartr) are concerned, it is on [the basis of] mere phenomena that [they] manage to

77 mrrdāder ghațādinimittatājñāne ] $\mathrm{S}_{3}, \mathrm{~J}^{\mathrm{R}}$, S12; om. S15.

78 kāraṇaṃ ghațasya ] $\mathrm{S}_{15}, \mathrm{~J}^{\mathrm{R}}$, S12; kāraṇaṃ gha[??] $\mathrm{S}_{3}$.

79 This annotation is not found in $\mathrm{S}_{3}, \mathrm{~S}_{15}, \mathrm{~J}^{\mathrm{R}}$ or $\mathrm{S}_{12}$, but it appears in both soAs (folio 106B, upper right corner) and $\mathrm{D}_{2}$ (folio ${ }_{115} \mathrm{~B}$, upper and right margins); it is also found in note 248 in İPV, vol. I, 19o. In all three cases this passage is preceded by a quotation from İ PVV, vol. II, ${ }_{165}$ (from bāhyatvaviśișto 'rthah up to kramikābhāsavaicitryāt). This i Pvv quotation is also found in S9, Sio and followed in all cases by ity āśankyāha grāmagrhāder iti. But after that point, while S9 and S1o add ayam äśayah and then quote again the ĪPVV from nedam bāhyatvam ghațasya onwards, SOAS, D2 and the İPV note give tathā cātra pūrvaryavasthā sphuțam eva drśsyate yatha and then the text quoted above. There is very little direct evidence that this annotation is indeed a quotation from the Vivrti: the only İ PVV passage that could comment on it apparently explains a sentence beginning with nanu cakșurādi॰ ${ }^{\circ}$ (see İPVV, vol. II, 165), whereas no nanu is to be found in the annotations and I had to conjecture it. Nonetheless, it seems to me quite probable that the words preceding cakșurādi ${ }^{\circ}$ are not part of the quoted text, as I cannot understand the sentence with the presence of the word yatha twice (the KsTs edition has $v \bar{a}$ after the second yatha although this $v \bar{a}$ is found neither in D2 nor in SOAS; but even with this additional $v \bar{a}$ I fail to see the structure of the sentence). Besides, as shown in Ratié 2011b, 491-499, this passage expresses a crucial objection against Utpaladeva's reasoning, and it is at least certain from Abhinavagupta's explanations in the I PVV (see below, note 119) that the Vivrti stated this very objection in a passage beginning with nanu cakșurādio. So it seems likely that this passage is a genuine fragment from the Vivrti, although this is by no means certain.

8o nanu ] conj.; om. D2, soAs (see above, note 79).

81 yathā bïjādyanubhavāt ] D2, soAs; yathā vā büjādyanubhavāt note 248 ĪPV (vol. I, 190).

82 kāraṇatāsāmānyam ] conj.; kāraṇasāmānyam D2, sOAs, note 248 Ī PV (vol. I, 19o).

83 evājñānaviśeșeṇa ] conj.; eva jñānaviśeșeṇa $\mathrm{D} 2$, soAs, note 248 İPV (vol. I, 19o).

84 vyāpāra ] D2, note 248 İPV (vol. I, 190); vyāpārā SOAS. 
successful[ly] ascertain ${ }^{85}$ the existence (vyavasthā) of [this or that] entityan ascertainment in which [they necessarily] engage [in their ordinary activities]; so this pondering over an unperceived reality that is [supposedly] something more (adhikatara) [than phenomena and the consciousness manifesting them] ${ }^{86}$ is a [purely] arbitrary endeavour ${ }^{87}$ For it is not [universally acknowledged that] no [perception] at all can be accounted for (upapadyate) without speculating about the [imperceptible] sense organs; $; 8$ thus some ${ }^{89}$ propound

85 See ĪPVV, vol. II, 131: nirapāyety apāyaḥ pramānāahōôvo dūṣaṇasambhavaś ca, tadrahitā. "[This ascertainment] is successful[ly performed] (nirapāya), i.e.,] it is devoid of the failure (apayya) [consisting in] the lack of a means of [valid] knowledge, and [it is devoid of] the possibility [that the means of valid knowledge] may be refuted."

86 The word adhikatara is the comparative form of adhika, which by itself means "something more." According to Abhinavagupta, Utpaladeva uses it because if the manifestations of objects in consciousness are something more than the consciousness manifesting them, the so-called external object must be considered as something more than these very manifestations: the external object must be considered as existing over and above phenomena and the consciousness taking their form - which is absurd. See İPVV, vol. II, 131: adhikatarety ābhāsā eva darpaṇāt pratibimbānīva saṃvedanād adhikāni, yac ca tato 'py adhikataram na kvacid bhāvi tat tata eva* drșțam tac ca vastu katham. [ "tat tata eva conj.; tata eva J10, J11, T, İPVV]. ' 'adhikatara' [means the following]: the [various] phenomena are [something more (adhika)] than consciousness, just as reflections are something more than a mirror [reflecting them]; and that which is something more than something more, [i.e., that which is something more] than these very [phenomena,] can never be perceived in any [circumstance] for the very [reason that it is distinct from phenomena]; and how could that be a [real] entity (vastu)?"

87 Cf. İ PVV, vol. II, 131: svacchandaceștitam iti na pramānabalopanatam ity arthah. "[It is] 'a [purely] arbitrary endeavour, i.e. it is not brought about by the force of [necessity inherent in] a means of [valid] knowledge."

88 Cf. İPVV, vol. II, 131: dṛștạn cedam prāmāṇikānāṃ yat saty api vastuny anupayogināṃśena na prayasyanti vicāritena yathendriyādișu șaḍhātusamīkșākārāadyā bārhaspatyā vā. ekair* hi bhūtapañcakam cetanā cetīyati vyavahārasamāptir añgīkrtā tatraivānyasyendriyāder anupraveśāt. anyair api bhütacatușțaye vicitramelanoditasaṃvedanākhyavikāraviśeșe 'nuditatadvikāre ca grāhakagrāhyavyavahārasamāptir upagatā. [ ${ }^{*} s ̦ a d ̣$ dhātusamikṣākārādyā bārhaspatyā vā T; șaḍdhātusamīkșākārādyo vārhatyo vā J1o, J11; șaḍātusamīkṣākārādyo bāa $(v \bar{a})$ rhatyo vā ĪPVV. *ekair J10, J11, T, Ka (quoted in ĪPVV, vol. II, 131, note 1); etair ĪPVV.] "And [we] observe the [following] among philosophers (prāmānika): even if [something] exists [as] a real entity, they do not concern themselves with the aspect [of it] that is useless [and] speculative (vicārita) —for exemple, regarding such [imperceptible things] as the sense organs, [this is the case of philosophers] such as the author of the Șaddhātusamīkșā, or of followers of Bṛhaspati. For the former acknowledge that ordinary human practice is accounted for if this much [is admitted]: the five elements and consciousness, because such other [things as] the sense organs are included in these; whereas the latter admit that the ordinary human practice [consisting in the relationship between] an apprehending [subject] and an apprehended [object] is accounted for if a particular transformation called 'consciousness' arises in the four elements from [some of their] var- 
the theory of the six elements (șaddhātu) while not taking the sense organs into account in any way, [and] others ${ }^{90}$ defend the theory of the two [sorts

ious combinations, and if this transformation does not arise [from other combinations of the four elements]." On the author of the Șaḍdhätusamīkșa and the followers of Bṛhaspati see below, notes 89 and 9o, and Ratié 2018 .

89 According to Abhinavagupta's commentary (see above, note 88), their "theory of the six elements" (șaḍhātuvāda) includes a set of five elements (bhütapañcaka)—i.e. most

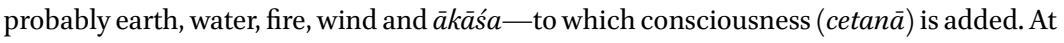
first sight one might assume that Utpaladeva and Abhinavagupta had a Buddhist author in mind (on the Buddhist theory of the șaddhātu see e.g. Abhidharmakośabhāssya 28 [on Abhidharmakośa 1.27]: ya ime tatra șad dhātava uktāh prthividhātur abdhātus tejodhātur vāyudhātur ākāśadhātur vijñānadhātuh ...; cf. La Vallée Poussin 1923, 49, note 2 for sources). But according to Abhinavagupta's commentary (ibid.), here Utpaladeva is rather hinting at the Saddhātusamīkșa - a lost work ascribed to Bhartṛhari. This treatise, alluded to by Somānanda in Śivadrșți 2.73 as the Samīkșā and mentioned by Utpaladeva himself in Śivadrșțivrtti, 83-86, is also known as the Śabdadhätusamīkșā (see e.g. Iyer 1969, 910), but as already pointed out in Torella 2002, xxvi-xxvii, note 39 (cf. Torella 2014, 573), the latter title, which appears in the KsTs edition of the Sivadrștivrtti, is a corruption (note that as seen above, note 88, the İPVV gives the title as Șaḍhātusamīkșā). On the few known fragments of it and what might have been the overall goal of the work, see Ratié 2018. As pointed out there, Abhinavagupta makes some interesting remarks regarding this șaḍhātuvāda while commenting on another part of the Pratyabhijñā treatise (ĪPVV, vol. I, 93): sānikhyasya yady api pañcavimiśatis tattvāni sphuranti, tathāpi pañcaiva bhūtāni cetanā cety etāvanmātre tāvat sākșātkārarūpo 'nubhavo nādhike. tata eva tatrabhavato dhātușațkanirūpaṇa eva viśvam nirūpitaṃ bhavatītyāśayena tatsamīkṣodyamah. saṃbhāvanānumānāgamajaniteșv api jñāneșu tad eva bhāsate, kevalaṃ yojanāmātram adhikam. yathā prthivy eva yā surabhyasurabhyādivicitragandhā tatraiva viśeșatyāgena saukșmyeṇa ca gandhatanmātrarūpateti. "Even though for a [follower of] Sānkhya, the twenty-five principles (tattva) are manifest [as the universe], to begin with, experience (anubhava), that is, immediate perception, consists in nothing but this: the sole five elements $($ bhüta $)$ and consciousness $($ cetanā $)$-and nothing more. This is why for the master [Bhartṛhari] (tatrabhavant), the universe is [entirely] explained as soon as the six elements are explained - it is with this intention that he has undertaken their Examination $($ Samīksa $\bar{a})$. It is also this [set of six elements] that is manifest in cognitions that arise from hypothetical inferences or scripture [and not only in perceptions; and] anything else is nothing but a mere combination [of these elements]. For example, [the property of] consisting in the subtle sensory object (tanmätra) of smell lies in the [element (dhātu) of earth] — that same earth that may possess various smells, some pleasant, others unpleasant, etc.-insofar as [earth] is devoid of particularities and subtle." So it seems that Utpaladeva alluded to this theory at this point of the Vivrti because according to the author of the Șaddhātusamīkșā, perception can be explained in its entirety as the result of a mere combination of the six elements, without inferring the existence of imperceptible indriyas that would be fundamentally distinct from these elements; or, as Abhinavagupta puts it (see above, note 88), according to this theory the indriyas are already included within the six elements.

If we follow Abhinavagupta's interpretation of this passage (see above, note 88), these 
of combinations of four elements-namely, the sort that produces consciousness and the one that does not-without taking imperceptible sense organs into account either]. And exactly in the same way, ordinary human practice [can] be entirely accounted for (parisamāpti) without any investigation about an absolutely imperceptible object [considered as] something more than phenomena. Therefore speculating about this [absolutely imperceptible object] is [nothing but] air.

Nor [can] the [external object] be established by any [such] speculation, because of the impossibility of this external [object]—-this is what [the verse]

"others" are "followers of Bṛhaspati" (bārhaspatya), i.e. some materialists (cārvāka) who embrace the ideas expressed in the sütras traditionally ascribed to Brihaspati (on the known fragments of this work and the probability that it was written around the sixth century, see Namai 1976, Bhattacharya 2002 and Franco 2011, 634-636). According to Abhinavagupta, they understand the relationship between the apprehending subject and the apprehended object as the mere result of various combinations between four material elements. Thus the fragments of the Brhaspatisütras do not deny the very existence of sense organs, but they refuse to see them as distinct entities: whereas the Nyayya and Vaiśeșika theories of vision for instance present the visual organ as an imperceptible ray of light fundamentally different from the perceiving body and perceived object (see e.g. Preisendanz 1989), the materialists see the indriyas as mere aggregates made of the same matter constituting the subject and object. See fragments A2 to A4 in Namai 1976, 39 (cf. Bhattacharya 2002, 603-604 and Franco 2011, 635): prthivy āpas tejo vāyur iti tattvāni $\|$ tatsamudāye śarīrendriyavișayasañjñăh || tebhyaś caitanyam || "Earth, water, fire and wind are the principles. [It is merely] their aggregates that the terms 'body,' 'sense organ' (indriya) and 'object' designate. Consciousness [arises] from these." Besides, according to the "follower of Bṛhaspati" whose views are mocked by Jayanta Bhața (the term bārhaspatya appears e.g. in Nyāyamañjarī, vol. I, 496 and Āgamadambara, 63), inferences are valid only if they regard entities that have already been perceived, but not if they are meant to establish the existence of entities that are by nature imperceptible, such as God and the Self. See Nyāyamañjarī, vol. I, 326: dvividham anumānam, kiñcid utpannapratīti kiñcid utpādyapratīti. ìsvarādyanumānam tūtpādyapratīiti. tatra dhūmānumānādeh prāmānnyam kena neșyate | ato hi sādhyaṃ budhyante tārkikair akșatā api || yat tv ātmeśvarasarvajñaparalokādigocaram | anumānaṃ na tasyeștam prāmāṇyạ̣ tattvadarśibhị || "Inference is of two sorts: one [concerns an object] the perception of which has [already] occurred [at some point]; the other [concerns an object] the perception of which has [yet] to occur. But the inference of [entities] such as God [concerns an object] the perception of which has [yet] to occur. Among these [two types of inference,] who would not admit the validity of an inference such as that [of fire] from smoke? So [people] apprehend what is to be established [by such an inference] even though they are not pestered by logicians. But the validity of an inference regarding such [entities] as the Self, God, an omniscient or an afterlife is not acknowledged by those who know reality."

Whether the materialists of Jayanta's time had also explicitly targeted the inference of the indriyas or not, Jayanta criticizes their thesis by emphasizing that it leaves them with no choice but to reject the inference of imperceptible indriyas as well. See Nyāyamañjari, vol. I, 501: śrotrādyanumāne 'pi yathodāhrte śakyam evam abhidhātum ... "And also with 
says with "syād etat."11 And [since it is] so, since only phenomena [can] be objects, the manifesting consciousness ( prakāśa) is the object, and conversely the object is the manifesting consciousness; therefore they consist in each other. ${ }^{92}$

$[\ldots]^{93}$

respect to the inference of the hearing organ and so on, according to the way in which it is formulated, one can declare similarly, [as in the case of the inference of God or the Self, that it is invalid] ..." Cf. Ágamaḍambara, 68, where the Saiddhāntika arguing with a Cārvāka who denies the validity of the inference of iśvara points out that then the Cārvāka should equally dismiss the inference of the indriyas. The Cārvāka replies: "Let [us admit that] the [sense organs] too are not inferred; why should it be a problem for us?" (tad api mānumāyi, kiṃ naś chinnam); the Saiddhāntika asks in turn: "But [then] how can you see a visual form without any visual organ?" (nanu cakșuṣā vinā katham rūpam drakṣyasi). See Dezső 2005, 168-169. On the possibility that the materialist portrayed by Jayanta might be a caricature of a ninth-century Kashmirian materialist, poetician and grammarian named Udbhața, see Solomon 1977-1978, Bronkhorst 2008 and Bronner 2016. Cakradhara, while commenting on the Nyāyamañjarī, explicitly identifies Jayanta's materialist target as Udbhața, to whom he ascribes a commentary on the Brhaspatisütras (see Solomon 1977-1978, 988-990), and it is not impossible that Utpaladeva and Abhinavagupta also knew this work.

91 Utpaladeva has just argued that there is no universal acknowledgement of the necessity of positing the existence of imperceptible entities (such as the indriyas) so as to account for perception. He now adds that even granted that we admit this necessity (hence the "Let us admit this," syād etat, in the verse), such an argument is in fact invalid because, as he is about to show, the existence of the external object is contradictory to reason. Cf. I PvV, vol. II, 131: anupayogino 'pi vastuvicāracakșuranveșyatvāt* tattvam, iha tu bāhye 'rtha idam api nāstìty āha nāpīti. [ "vastuvicāracakșuranveșyatvāt conj.; vastuno vicāracañcuranvișyatāt İPVV, vastuvicāracañcuranveșatāt T; vastuvicāracaṃcaranvisyatāṃ J10, J11.] "[With] 'Nor ...', [Utpaladeva] says that [something may be considered as] having a reality (tattva), even though it is useless [in ordinary human practice], on the grounds that [the existence of] the visual organ [for instance] is required when speculating on the real entity [that contributes to the production of a visual perception]; but in the [case of the] external object, there is not even [room for] such an [assumption]."

92 See ĪPVV, vol. II, 131: parasparātmaketi. krayavikrayāder api tathāprakāśanam eva prānāhạ. yad evedam yasyettham ${ }^{*}$ prakāśate tad etenaiva mama prakāśamānasya prakāśamānāyām evārthakriyāyām upayogah. ["Parasparātmaketi conj. (see above, note 50); pratītiparamparātmaketi $\overline{\mathrm{I}} \mathrm{PVV}, \mathrm{J} 1 \mathrm{O}, \mathrm{T}$; pratītiparasparātmaketi J11. *yasyettham conj.; asyettham $\overline{\mathrm{I}} \mathrm{PVV}$, J10, J11, T.] "[They] 'consist in each other' [means the following]: even the essence of [ordinary human practice] such as buying and selling, etc., is nothing but such a manifesting consciousness. Only that which is manifest in such a way is for this very reason useful [in providing] to me, for whom [this thing is manifest and while I am] being manifest [myself], an efficacy which is [itself] necessarily manifest!" That is to say, as far as I understand the passage: objects can be desired and aimed at by a subject in the sphere of human practice only if they are forms taken on by the subject's consciousness, and are ultimately nothing but the manifesting consciousness itself.

See above, note 51 . 
[2] Even an ordinary human practice that is based on an inference[- such as trying to reach a fire the presence of which is merely inferred from the perception of smoke-can only occur] thanks to a fire that is necessarily being manifest [at the very time of this endeavour]; even in a conceptual cognition, fire is determined [as being] external [to consciousness only insofar as] it is manifested. ${ }^{94}$ It is for this reason that an activity [can occur] with respect to

94 Cf. İPVV, vol. II, 131-132: bāhya eveti saugatais tāvad adhyavasāyabalāt prāmānnyam vadadbhir anumānam api bāhyavișayam evety uktam prāmānyam vastuvișayaṃ dvayor apīti. asmanmate tu vikalpasyāvaśyam vastunișțhatvam evety uktạ̣ bhrāntitve cāvasāyasyetyādyantare. tata eva yad āha bāhyavādì vikalpasyāsatyaprakāśanatvam iti, tad asmanmate niravatāraṇam eva. sākārajñānavādinā vikalpaḥ svātmani prakāśạ, arthe tv avasāya ity ukte katham asatprakāśanam. tad āstām tāvat. "[Here is what Utpaladeva means with the words] ba ahya eva. To begin with, the Buddhists, when saying that the validity of a means of knowledge arises from the force of determination (adhyavasāya), admit that even inference must have an object that is external [insofar as it is based on the determination of a previously perceived object. This is what Dharmakīrti has said in Pramānaviniścaya $2.7 \mathrm{~b}$ ]: 'In both [inference and perception], the validity [of the means of knowledge] concerns a real thing .... But in our doctrine, the concept necessarily rests on the real thing, [even at the time of conceptualization: Utpaladeva] has [already] stated this elsewhere, for instance in [verse 1.3.5 beginning with] bhräntitve cāvasāyasya. For this very reason, in our system the [Buddhist] externalist's claim that a concept involves no real manifestation cannot be accepted at all: since the proponent of the theory that cognition has aspects says that a concept is [immediately] manifest in itself [insofar as every cognition is immediately aware of itself,] even though with respect to the object, [this concept] is a [mere] determination, how could it have a nonexistent manifestation? So enough with this."

Here is the gist of Abhinavagupta's reasoning as I understand it. The Buddhists see conceptualization as bearing on a mere generality or a pseudo-object resulting from a process of exclusion (apoha); yet they acknowledge (as Dharmakirti in the Pramānaviniścaya) that a valid inference has as its object a real entity inasmuch as its object is capable of efficacy (see Pramānaviniścaya 2, 48: ... arthakriyāyogyavișayatvād vicārasya, "because a [valid inferential] speculation has an object that is capable of efficacy"). According to Dharmakīrti, this is the case because although the generalities aimed at in concepts are no real entity (since reality is purely singular), they result from the determination (adhyavasāya) as one single entity of many perceived singular entities that have a somewhat similar efficacy (thus the concept of "fire" results from our determining as one many perceived fires that are all in fact different from each other but share the capacity to burn, etc.). So even inferences are somehow based on at least one aspect of perceived entities (namely arthakriya $\overline{\text { ) }}$, and this is why valid inferences enable us to obtain desired entities and to shun undesirable objects. Nonetheless, the Buddhists consider that only perceptions involve an immediate manifestation of the object, and the Śaivas see this as a contradiction in the Dharmakirtian system: according to Abhinavagupta, the Buddhist theory of determination entails that conceptual objects too are directly manifested at the very time of their conceptualization (and not only in some perception anterior to the conceptual elaboration), at least as regards their efficacy (see e.g. İPVV, vol. II, 132: 
[something determined as being] external, and that an activity [can occur] with respect to [something determined as being] fire. Ordinary human practice [can even occur] with an object such as the sense organs, or heaven and liberation, although [these always remain] beyond the reach of the sense organs, [but] only inasmuch as they are [somehow] manifest in the concept [representing them]. ${ }^{95}$ And [since it is] so, being an object is nothing but having a

arthakriyāpi cābhāsamānatayaivābhilașaṇīyeti sāpy ābhāsaviśrānteti. "And even efficacy can be desired only insofar as it is being manifest; therefore it too rests on manifestation."). Besides, the Buddhist epistemologists cannot deny that concepts involve a real, immediate manifestation since they consider that all cognitions have two aspects ("an aspect [consisting in] the object," vișayākāra, and "an aspect [consisting in] themselves," svākāra), and that even concepts, insofar as they possess self-awareness (svasamvedana, svasamvitti), involve an immediate manifestation of themselves (on this idea and its appropriation by the Śaivas see Ratié 2011, 44-45, note 20).

Abhinavagupta thus emphasizes in this passage the major point of contention between the Śaiva nondualists and their Buddhist counterparts as regards concepts: according to Utpaladeva, all concepts involve the immediate manifestation of a real thing at the very moment when they arise, because there can be no conscious representation of something that consciousness cannot present to itself in an immediate way; without such a manifestation, concepts could not occur or would be similar to a state of unconsciousness. And this means that even objects conceptualized as being external are ultimately internal aspects of consciousness manifesting itself as if it were external to itself. See e.g. İPVV, vol. II, 129-130: anumito 'pi bāhyo 'rtha h prakāśamāna eva vaktavyaḥ, prakāśād bhede hy aprakāśanaprasañgād anumitatvam api vastuno mürchāprāyam bhavet. "Even [if] an external object [is] inferred[, it] can be talked about only insofar as it is being manifest, for if [it] were distinct from the manifesting consciousness (prakāśa), since as a result it would not be manifest, [the awareness of] the very fact that the entity is inferred would amount to a state of stupor!"

95 Cf. İPVV, vol. II, 132: vikalpapratibhāsinety* upalabdhikriyākaraṇatayā sāmānyendriyaṃ, niratiśayasukhatatsādhanavișayatayā svargaḥ, anāhṛtasahajānandaghanataikasāraparipūrnatātmanāpavargaś* cābhāsabhuvam abhyety* eva, anyathābhilașaṇīyatvatatsādhanānveșaṇatadrūpadeśatadavadhāraṇatadanușthānādyayogāt. [ " vikalpapratibhāsinety J11; vikalpapratibhāsitety ĪPVV; vikalpapratibhāsanety T, J10. *oparipūrnatātmanāpavargaś T; ำūrnatāpavargaś İ PVv, J10, J11. * cābhāsabhuvam abhyety T; cābhāvabhuvam abhyety ĪPVV; cābhāva .. satyety J10; cābhāvam abhyety eva J11.] "[The passage] 'inasmuch as they are [somehow] manifest in the concept [representing them' means the following]. The 'sense organ,' [apprehended as] a generality (sāmānya) [by conceptual thought, i.e.,] as the instrument of the action of perceiving, [as well as] 'heaven,' [apprehended] as the object of unsurpassed pleasure and as [the means of] realizing it, and 'liberation,' [apprehended] as consisting of an absolute fullness the essence of which is nothing but the plenitude of a bliss that is not brought about [because in fact it is] innate-[all these] must belong to the realm of phenomena; otherwise such [things] as the fact that [they] can be desired, the search for the realization of this [desire], their determination [as having] this [particular] form and place, the practice in accordance with [this determination], etc., would [all] be impossible." 
form that is [presently] being manifest, and the goal [of human practice] only concerns what is merely such [and nothing beyond manifestation].

[If you reply:] "But this [property of being an object] can only belong to [things] that are distinct from manifestation," what apprehension [of these objects] could there be [if they are distinct from manifestation] ${ }^{96}$ [And] what is this [so-called] annihilation of ordinary human practice [that must inexorably occur according to you] if [objects] are one with phenomena? This is what [the $V r t t i$ ] says in "let [us admit that] they consist in phenomena." ${ }^{\prime 97}$

Only [the following] could [still] be objected: ${ }^{98}$ if these [objects] did not exist after as well as before [their] being manifest, [then] the very fact that they

96 Here the opponent is arguing that by definition, an object is what we apprehend as being distinct from-i.e. external to-us considered as conscious subjects, so that the idealist's thesis is absurd because it contradicts our most ordinary experiences in the sphere of human practice. He is therefore implicitly invoking the evidence of common knowledge (prasiddhi) to show that there must be some external object. Utpaladeva answers that this evidence, far from being contradictory to his idealism, is in fact an argument in favour of it. Cf. İPVV, vol. II, 132: tataś ca prasiddhyaiva bähyah sidhyatīti pratyuta viparītam etat ... "And therefore, [to the objection:] 'the external [object] is established through mere common knowledge,' [one should answer] that it is rather the contrary." According to this fragment, the reason why this is so is that apprehending an object means making the object manifest to consciousness, and such a manifestation can only occur if the object is nothing but consciousness taking the form of an object. This idea is justified at length at the beginning of chapter 1.5 (see Ratié 2011, 309-366).

97 Cf. the beginning of Vrtti on İPK 1.5.6, 20: äbhāsamānair evārthair vyavahārah, te cābhāsātmakāh santu, kā kșatih. "Ordinary human practice occurs thanks to objects precisely insofar as [they are] being manifested, and let [us admit that] they consist in phenomena [and nothing else] - what harm [might ensue for human practice if it is the case]?" See Torella 2002, 114.

98 See ĪPVV, vol. II, 132-133: ābhāsānām eva vastutām abhidhāya prāmāṇikatvāt svayam svapakṣe dūṣanam āśañkya darśayaty āśayaśuddhipradarśanena vittarāgatāṃ* vaktum kevalam iti. paryanuyojyam idam paryanuyogārham, kim, āha ābhāsamānatāyā iti. pürvam

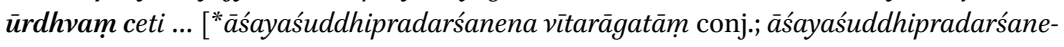
nāvitārakatām ĪPVV, J1O, J11, T.] "Having explained that only phenomena are real entities because [only they are] established by a means of [valid] knowledge, [and] anticipating by himself the refutation of his own thesis, [Utpaladeva now] expounds [this refutation with the passage beginning with] 'only ...' by empasizing the purity of his intentions, in order to state that [he] is free of bias. [According to him] this 'could [still] be objected,' [i.e.] it deserves the [following] objection. Which one? This is what [Utpaladeva says] in '[if these objects did not exist] after as well as before [their] being manifest ...'" My tentative emendation above (vītarāgatām instead of avitärakatām) is based on passages such as Nyāyamañjarī, vol. I, 25: "and it [i.e. tarka] can be used in order to show [one's] purity of intentions in a debate" (sa cāśayaśuddhim upadarśayitum vāde prayokșyate). Cakradhara (Granthibhanga, vol. I, 17) explains that it can be used "in order to make clear '[one's] purity of intentions,' [i.e.] the fact that one is free of bias" (äśayaśuddhim vitarāgatvam prakațayitum), and he adds: tarkakrameṇa svārthānumānakāle yathā prati- 
are manifest would be causeless, and [under such conditions,] the relation of cause and effect and the relation between the knowing subject and the object of knowledge would not be possible. ${ }^{99}$

$[\ldots]$

[3] If, on the other hand, ${ }^{100}$ external objects are only atoms that are partless [and] aggregated, even so, a pot, which appears in a [spatially] extended

pannah svayam asā̄ arthas tathaiva parasya pratipādyate, vîtarāgakathātvād vādasyeti. "Through the method of tarka, something is demonstrated for the opponent exactly as it was understood by oneself at the time of an inference for oneself, because a debate is a discourse of [people] who are free of bias." This is an allusion to the Naiyāyikas' distinction between three kinds of discourse, namely debate ( $v \bar{a} d a)$, disputation ( jalpa) and sophistry (vitaṇdā), and the Śaivas are well acquainted with it. See e.g. Kșemarāja's Svacchandatantroddyota, vol. vI, 98 (alluding to Nyāyasūtra 1.2.1, according to which "debate comprehends both the thesis and the antithesis," ... pakșapratipakșaparigraho vādah): ... pakșapratipakșaparigraho vītarāgakathārūpo vādaḥ. "Debate, which comprehends both the thesis and the antithesis, [and] which is a discourse of [people] who are free of bias ..." On vāda as a vìtarāgakathā see also e.g. Nyāyamañjarī, vol. I, 18 or Nyāyabhūșaṇa, 328; cf. Tanträlokaviveka on Tantrāloka 13.126, vol. viII, 9o. So as far as I understand the İPVV passage, Abhinavagupta simply means here that by raising himself (svayam) this objection to his own thesis, Utpaladeva is showing to his opponent that he is an unbiased interlocutor.

99 Cf. İPVV, vol. II, 133, which explains the objection in the following way: ... äbhäsanam avaśyam bhavane cābhavane ca nimittam apekșate. tac cen nāsti, tan nirhetukatā. tataś ca kāryakāraṇābhāvād ghațārthī na mṛdam āharet, na kumbhakārakulam abhigacchet, na dhūmārthī hutabhujam ādadīta. kāryakāraṇatāmūlaś ca jñāpyajñāpakabhāvah ... "A manifestation necessarily requires a cause as regards both [its] arising and [its] not arising. And if there is no such [cause], then [this manifestation] is causeless. And since as a consequence there is no relation of cause and effect, [someone] who wants a pot should not get clay [and] should not go see a family of potters; [and someone] who wants smoke should not get himself a fire. Moreover, the relation between the knowing subject and the object of knowledge has as its root the relation of cause and effect ..." As for the gist of Utpaladeva's reply to this objection according to Abhinavagupta, see above, note 3 .

100 This fragment, which targets the Buddhist Vaibhāṣika theory according to which external objects are nothing but aggregated atoms, must have followed a criticism of the Vaiśeșika thesis that the external object is a whole (avayavin) distinct from its parts (avayava), hence the atha here. See ĪPVV, vol. II, 140: evam kānāādasammatam bāhyam dūṣayitvā vaibhāṣikaparibhāṣitam api dūṣayaty atheti. "Having thus refuted the external [object as it is] understood by the followers of Kanāda, [Utpaladeva now] refutes as well [the external object as it is] explained by the Vaibhāșikas [in the sentence beginning with] 'If, on the other hand." This line of argument is of course borrowed from the famous criticism in Vimsíika $11-15$ of the various theories claiming to account for the external object. Vasubandhu shows there that we cannot make sense of this external object whether we try to understand it as a whole distinct from its parts, as atoms taken individually, or as aggregated atoms. On the recent debate as to whether Vasubandhu's reasoning was meant to show that the external object cannot exist, or whether his goal was merely to point out that such an object cannot be known, and for convincing arguments in favour of the first hypothesis, see Kellner and 
form, necessarily appears as having [different] parts [respectively located in the] east, west, etc.; and [this spatial extendedness] ${ }^{101}$ is not possible if [this pot] is thus made of atoms[, since by definition an atom cannot have different parts]. ${ }^{102}$ To explain: ${ }^{103}$ a second atom that is connected with the atom considered as the first [one] $]^{104}$ must be one with this [first atom]; for if [these atoms] devoid of parts are in contact, how much [of them could] remain that

Taber 2014; on the Śaiva nondualists' unambiguous interpretation of the Vimiśikā along the same lines, see Ratié 2014. On Vasubandhu's refutation—summed up in this fragment—of the Vaibhāṣikas' atomism, see e.g. Kapstein 2001, 181-204; for Abhinavagupta's explanation of it, see Ratié 2010, 450-452, and Ratié 2011, 395-399.

101 Cf. İ PVV, vol. II, 140: na caivam paramāṇumayatva iti vaitatyam digbhāgabhedavattvam. "And [spatial] extendedness, which [consists in] being differentiated into parts according to the directions, is "[not possible] if [this pot] is thus made of atoms."

102 The main idea is that if perceptible things, which are made of imperceptible atoms, are spatially extended, the atoms too must have such an extendedness, but spatially extended atoms must have parts, which is absurd since the atom is by definition partless. Cf. Vimśikā 14ab: digbhāgabhedo yasyāsti tasyaikatvam na yujyate | "That which is differentiated into parts according to the directions cannot be one." See also Vimiśikāvrtti, 7: anyo hi paramānohoh pūrvadigbhāgo yāvad adhodigbhāga iti digbhāgabhede sati katham tadātmakasya paramānor ekatvam yokssyate. "For if an atom has one part in the direction of the east, [and others in the directions of the south, west, north, above] and below, given that [the atom] is differentiated into [various] parts according to the directions (digbhāgabheda), how could the atom be one [whereas it] consists of these [different parts]?"

103 According to Abhinavagupta, here Utpaladeva has the externalist face a dilemma, the first part of which remains implicit in the Vivrti. See ĪPVV, vol. II, 140: tac ca bahūnām paramānūnām bhinnadeśatve mūrtatvenānyonyarūpadeśäkramanayogyatvābhāvāt * pratilabdhe kimiti na ghațata ity āśan்kyāha tathā hìti. ayaṃ bhāvaḥ-yadi sāntarāḥ paramāṇavo ghațah, tad adrśyatā ... [ ${ }^{*}$ uurrtatvena ${ }^{\circ}$ corr.; 'mūrtatvena ${ }^{\circ} \bar{I}$ PVV.] "[The opponent:] 'And why is [this spatial extendedness of the pot] not possible if [we admit that] the numerous atoms get to have different places because, since they are of a material, [i.e. solid] nature (mürta), [they] cannot extend to the place of the others' forms?' Anticipating this [objection, Utpaladeva] says 'To explain ...' Here is the implicit meaning [of this passage]: if the pot is [nothing but] atoms with intervals [separating them from each other], then [the pot] must be imperceptible ..." In other words, the opponent is tempted to respond to the objection just stated in the fragment by explaining that atoms can indeed occupy different locations because although partless, they cannot penetrate each other so as to coexist in the same spot. But this reply is unsound, first and foremost because then the macroscopic pot should remain imperceptible, as it would merely consist of imperceptible atoms and intervals between them. After enumerating a few more of the "countless defects" (śataśo doșāh) inherent in the thesis that atoms are separated by intervals, Abhinavagupta adds (ibid.): nairantarye tu parasparasamśleșah. "But if [the atoms] are contiguous, they [must] be in contact with one another." It is the absurdity of the latter hypothesis that the fragment is now going to point out.

104 Alternatively, one could understand: "a second atom that is connected with the atom considered as [located] in the east." 
might not be in contact? And [if they are thus entirely] in contact, their natures must be immersed in each other, therefore [they] can only be manifest as one [single] atom; and if [they are] in contact with yet another atom, the same [consequence follows] - therefore even if an infinite number of atoms were connected, they should be manifest as having the size of one [single] atom; ${ }^{105}$ or [rather], even this [manifestation] would not exist, because atom[s], [taken] one by one, are beyond the realm of the sense organs. ${ }^{106}$

\section{$7 \quad$ Translation of the Fragments on İPK 1.5.8-9}

[4] For inference is a concept, and this [concept] arises thanks to the residual trace (samskāra) [left by] a previous experience; so to begin with, [it] depends on the fact that the object was directly perceived [at some point] in the past, and inference is a conceptual cognition that arises as an unfailing (avyabhicāra $)^{107}$ [means of knowledge] with respect to this [previously perceived] object. ${ }^{108}$ And insofar as this [inference ${ }^{109}$ produces the realization (vimrśati)

105 If atoms are in contact, they must all share the same place since they are partless, and as a result their aggregate, however complex, cannot be larger than a single atom. See Vimsíika 12cd: șaṇnām samānadeśatvāt piṇ̣̂h syād anumātrakah| "If the six [atoms supposedly surrounding the first one] share the same location [as the first one], [they] must [constitute] a lump [of matter] that has the size of a [single] atom." Cf. Vimśikāurtti, 7: atha ya evaikasya paramāṇor deśạ sa eva șaṇnām. tena sarveșām samānadeśatvāt sarvah piṇḍah paramānumātrah syāt parasparāryatirekāt. "If, on the other hand, the place of one atom is also that of the six [atoms supposedly surrounding it], then since they all have the same place, [they] must all [constitute] a lump [of matter] that has the size of a [single] atom, since they are not distinct from each other." See also İPVV, vol. II, 141: iti dvāv api militau nādhikam rūpam samutthāpayeyātām. evam anyamelane 'pi vācyam. tad āha ananteti. "Therefore two connected [atoms] cannot bring about a form larger [than one single atom], and the same must be said if another, [third atom] gets in contact [with them] — this is what [Utpaladeva explains] with "[even if] an infinite [number] ...””

106 If aggregated atoms are not larger than one atom, no material object should be perceptible, since a single atom is imperceptible. Cf. Viṃśikāvrtti, 7: iti na kaścit piṇ̣̂o dṛśyah syāt. naiva hi paramānavah samyujyante niravayavatvāt. "So no lump [of matter] at all should be perceptible; for the atoms cannot be in contact [with each other] at all, since they have no parts."

107 Literally, "non-deviating."

108 According to Abhinavagupta, here Utpaladeva specifies that inference is a "non-deviating" means of knowledge (that is, according to the Buddhist epistemologists, a means of knowledge that is valid inasmuch as it unfailingly enables us to reach a given object) so as to point out that although conceptual, it is not a mere mental construct absolutely unrelated to perception, since it regards a previously perceived object. See İPVV, vol. I, 161: pūrvābhāta evānumānam ity etat sādhayitum tāvad āha anumānam hìti. yata evam tas- 
of this object-[which only] exists inside [consciousness at the time when we infer] - thanks to the residual trace of the [past] experience, [and insofar as it produces this realization] as is appropriate [for an object, i.e.] in the form "this" (idant $\bar{a}$ ), it only manifests [this object] as being separated [from the subject, the latter being expressed as "I"]. And this mere [realization that the object is something separated from the subject] is not enough to transform this object into something on which [human] activity may be exerted; therefore [this object] is [also] made manifest ( prakāsitia) as having a specific place and time, because only a particular having a specific place and time can be something on which [human] activity may be exerted, since [only such a particular] can be obtained ( präpya) and since [only such a particular] may have the efficacy (arthakriy $\bar{a})$ that [we] expect [from it]. So [a valid inference is] an act of realization (vimarśana) that is exactly so, [i.e. it is an unfailing means of knowledge with respect to a previously perceived object that it manifests as having a specific place and time]. ${ }^{110}$ This is what [the Vrtti] says [with the words] "manifested in the past" ( pürvāvabhäta), "an object invariably concomitant [with this entity]" (nāntarīyakärtha) [and] "[due to the association of this entity with] this or that [specific] place and time, etc."111

mādyuktah sūtrārthaḥ. nanu vikalpamātram eva kim anumānam. netyāha avyabhicāreti* . [*avyabhicāreti conj.; avyabhicārīti J1o, J11, T, İPVV.] "In order to demonstrate that inference only regards a previously manifested [object], first [Utpaladeva] states [the sentence beginning with] 'For inference ...' [And] since [inference] is so, the meaning of verse [1.5.8] is justified. But is inference nothing but a mere concept? With [the word] aryabhicāra ${ }^{\circ}$, [Utpaladeva] answers 'no' [to this question]."

109 Cf. İ PVV, vol. II, 161: anumānam kartr prathayatīti sambandhah.

110 See ĪPVV, vol. II, 162: na ca tāvatety antahsthitasaṃskāraśeșasya bahīrūpatāvabhāsanalakșaṇena vicchedamātreṇābhāsitenāpi viśiștau deśakālau vinā kāȳȳyavyāpāraparyantapravrttijananam anumānena na krtam bhaved iti viśsiștadeśakālālingite 'rthe pravrttiyogye yad vikalpanam tat pramānarūpam avisampvādakatayānumānam ucyate. "And this ... is not enough' [means the following]. [Something] that [only] consists of the manifestation in an external form, [i.e. in the form 'this,'] of what remains [of the past experience in the shape of] an internal residual trace; [that is to say, something] that is merely separated [from the subject expressed as 'I,' but] that, although manifested, [appears] without any specific place and time- - [this is] not [enough] for inference to trigger any activity ending in a bodily action. Therefore what [we] call an inference is [not just any] conceptualization (vikalpana), [but only one] that consists in a means of [valid] knowledge since it is reliable (avisamvādaka), [and one] that concerns an object possessed of a specific time and place, [therefore being] fit to be [something on which] an activity [is exerted]."

111 Cf. Vrttti on Ī PK 1.5.8, 21-22: pūrvāvabhātāntahsthita evārthe nāntarīyakārthadarśanavaśāt tattaddeśakālādiyojanayā vimarśanam anumānam. "Inference is an act of realization (vimarśana) with respect to an object that exists internally [now in the form of a residual trace because] it has [already] been manifested in the past. [This act occurs] thanks to the perception of an object invariably concomitant [with this entity,] due to the association 
$[\ldots] \cdot{ }^{112}$

[5] Even a sense organ has already been experienced before [being inferred]; for this [sense organ] is not inferred in its own specific form, but rather, as a [mere] generality (sāmānya). ${ }^{113}$ This is what [I] say in the Vrtti [with the words] "a cause that is a mere indeterminate thing" (kiñcinmātra). ${ }^{114}$ The object [inferred in this inference of the sense organs] is a generality (sāmānya) [that simply consists in] being a cause; [and this generality] was manifested before [the inference] in the cognition that the seed is a cause of the sprout, [or] in the cognition that clay for instance is a cause of the pot and [other such objects]. ${ }^{115}$ For in that [cognition that the seed is the cause of the sprout], ${ }^{116}$ it is not [something] specific[, i.e.] only a seed [and nothing else], that is mani-

[of this entity] with this or that [specific] time and place, etc." As noted in Torella 2002, 117 , note 19, Utpaladeva's definition specifies that inference "aims at proving the existence of an object that is able to propose itself as the possible object of purposeful activity (i.e. specified by a definite time and space [...])." And this amounts to saying that the external object cannot be an inferential object, not only because there can be no previous experience of such an object, but also because according to Utpaladeva's definitions of time and space (on which see e.g. Ratié 2011, 197-201), spatial and temporal relationships can only belong to manifested entities. See e.g. İPV, vol. II, 16: nanv evam ābhāsavișayābhyām eva deśakālakramābhyām bhavitaryam. "But [if it is] so, the spatial and temporal sequences can only regard phenomena."

112 See above, note 75 .

113 On the Śaivas' understanding of this type of inference called sāmānyatodrșț (which infers the mere existence of some imperceptible and therefore indeterminate entity so as to account for a phenomenon that would remain inexplicable otherwise) see e.g. Torella 2002, 117, note 20, and Ratié 2011b, 486-488.

114 Cf. Vrtti, 22: indriyam apy anumīyate kiñcinmātram nimittam tac ca büjädyābhāsād ābhāsitam eva. "Even a sense organ is inferred [as] a cause that is a mere indeterminate thing; and this [sense organ] has already been manifested due to the manifestation of a seed, etc." See Torella 2002, 117 .

115 Utpaladeva considers every perceived object as a particular synthesis of general features (including that of causality); see Torella 1992, 332-333, and Torella 2002, 89-9o, note 3 . On Abhinavagupta's explanations of this point see Ratié 2011b, 488-491. It is this theory that enables Utpaladeva to claim here that although the sense organs are imperceptible in the sense that they can never be apprehended as singular entities existing in a determinate place and time, they can still be considered as having somehow been perceived before being inferred (so that their inference is valid); this is so because the inference of the sense organs does not concern a particular entity but a mere generality (that is, an indeterminate cause that must be postulated on top of other conditions such as light so as to account for the phenomenon of perception), and this general notion of causality is part of countless perceptions of particular fires seen as causing smoke, etc., since the perception of a particular is nothing but the apprehension of a synthetic unity of generalities, including causality.

116 Cf. İPVV, vol. II, 163: na hi tatreti büjasya nimittatājñāne. 
fested as a cause; [otherwise,] as a consequence [we] would not know that clay too [is a cause]. Nor is clay only [cognized as a cause] in a [cognition occurring] after [that of the seed being a cause], because [if it were so] there would follow that [we] would not know that the seed and so on [are also causes]. And [one should rather consider that] within this [notion of causality that is present in the perception of the clay] as well as [in that of the seed], a [process of] particularization leads to an exclusion [that takes the form]: "it is the clay that is the cause of the pot, not the seed"; [and this exclusion eliminates from the general notion of cause] that which [the particular cause] is not but which is intrinsically linked ( prasakta) [with the notion of cause in general].117

$[\ldots]$

[6] [118 [-Objection from the Sautrāntika:] But just as [you] have said that [in the case of the inference of the sense organs,] the generality "causality" has already been experienced through the experience of [particular causes]

117 Utpaladeva is arguing here that within any act of perception, the apprehension of universals or generalities (such as causality) comes first, and it is only once these general features are apprehended that we determine our perception as being that of a singular synthesis. This determination of the perceptual object as a singular entity takes the form of the mental process of exclusion (vyavaccheda, apoha) which, according to Dharmakīrti, produces generalities (Utpaladeva's system thus integrates the Dharmakirtian notion of apoha, but not without turning it upside down). In other words, upon seeing a pot being made out of clay, we first apprehend a number of generalities inherent in the clay, and then we exclude from e.g. the generality "causality" whatever falls into the general category of cause (or, as Utpaladeva says, is intrinsically linked with it) but has a different efficacy — seeds for instance. According to Abhinavagupta, it is because we thus apprehend the generality "causality" before the particularities of the perceived cause that we are capable of using the word "cause" to describe various entities. See ĪPVV, vol. II, 156: anyathaikatra bïje käraṇaśabdah sañketito na mrtpinḍādau sañketito bhavet. "Otherwise, the word 'cause' would be conventionally associated with one single [entity, such as] the seed, [but] it could not be conventionally associated with a lump of clay, etc." It is also this theory that enables Utpaladeva to claim here that in a sense, all causes (including imperceptible ones such as the sense organs) are perceived when we perceive clay, although contrary to the singular clay perceived at that particular time and place, all the other causes are only apprehended in the form of the general feature "causality." Cf. Abhinavagupta's explanation in ĪPVV, vol. II, 163: nanu kumbham prati mrdo nimittatājñāne bijjam api nimittabhāvena svīkrtam iti kutah. atrocyate prasakteti. prasangaś ca kāraṇatāsāmānyapratibhāsasamutthäpita iti bhāvah. "To the [question:] 'But how is it that in the cognition that the clay is a cause with respect to the pot, [we] apprehend the seed too as a cause?', [Utpaladeva] replies [with the expression] 'that which is intrinsically linked ( prasakta) [with the notion of cause in general].' And this intrinsic link arises from the manifestation of the generality [consisting in] causality — this is what [Utpaladeva] means."

118 On my reasons for thinking that this passage might be a fragment from the Vivrti, see above, note 79 . 
such as a seed, without considering the particulars that are the visual organ and so on, in the same way, [you must admit that] externality too has already been experienced as a generality from the experience of [various objects that are] external to the body, the house or the village, etc. Alternatively, if [you] claim that [the external object cannot be inferred because] there is no experience of externality through a particular [entity characterized as] not being consciousness, [then] since the visual organ and so on have not been previously experienced [as] a particular cause either, there can be no inference [of the sense organs either]; so why don't [you simply] admit that inference applies [in both cases]?119

119 I now think that my understanding of the last part of this sentence was mistaken in Ratié 2011, 466, note 221, and Ratié 2011b, 494, note 48. As for the general meaning of the passage, see ĪPVV, vol. II, 165: grāmād darpañād gṛhād dehāt samvedanād bāhyam iti bāhyatāsāmānyam* ekam, tac ca gṛhād bāhyam itipratītau siddham. tataśca samarpakam darpaṇād iva bāhyam ${ }^{*}$ saṃvedanād api setsyati kramikābhāsavaicitryād dhetor ity āśayena pūrvapakṣayati nanu cakșurādīti. [ ${ }^{*}$ bähyatāsāmānyam conj. Ratié $2011 \mathrm{~b}$, found in J10, J11, T, marginal annotations in SOAS, D2, and note 248 in ĪPV, vol. I, 19o; bāhyataḥ sāmānyam ÎPVV. *darpaṇād iva bāhyam conj. Ratié 2011b, found in T; darpanādibāhyam J10, J11, İPVV, marginal annotation in SOAS, D2 and note 248 I PV (vol. I, 190).] "With [the sentence beginning with] nanu cakșurādi-, [Utpaladeva] states the prima facie thesis [that he is about to refute] with the intention [of conveying the following objection]: It is one [and the same] generality of externality [that is present in these various cognitions: 'this is] external to the village, to the mirror, to the house, to the body, to consciousness.' And this [generality of externality] is established in the [mere] experience: '[this is] external to the house.' And as a consequence, [something] may be established to be external to consciousness as well and to project [its specific form onto consciousness], just as [something is external] to a mirror [and projects its specific form onto the mirror, and it may be established to be so] on the basis of the [logical] reason that is the variety of successive phenomena [experienced by any conscious being]." As to how, according to Abhinavagupta, Utpaladeva was answering this objection in the now missing Vivrti passage following this fragment, see ĪPVV, vol. II, 165: naivam* bāhyatvam ghațasya grāmāc ca saṃvedanāc caikam, saṃvedanād bāhyam hy asaṃvedanarūpam, na tu gṛād bāhyam agṛharūpam. evam sati hi gṛhaikadeśạ̣ kuḍādir gṛhāntarvarty api ca ghațādir gṛhabāhyah syāt. na caivam, grhasannikrștam ca yadvad* bāhyam gṛān na tadvad eva saṃvedanāt tasyāmūrtasya sannikarșādideśavyavahāryatvābhāvāt. tatah śabdasāmyamātreṇedam ${ }^{*}$ sādhyam ekam pratibhātīty abhiprāyenottarayaty atrocyata iti. [ ${ }^{*}$ naivam $\mathrm{T}$; nedam J10, J11, İ PVV. *ca yadvad T, İPVV; yadvad J10, J11, Kha (ĪPVV, note 1). *'śabdasāmyamātrenedam conj. Ratié 2011b, found in T; śabdasāmānyamātreṇedam Jı, J11, İPVV.] "In 'To this [objection we] reply ..., [Utpaladeva] answers [the objection] with [the following] in mind. The externality of the pot is not thus one [and the same whether it is considered] with respect to the village or with respect to consciousness; for that which is external to consciousness consists in that which is not consciousness, whereas that which is external to the house does not consist in that which is not a house! For if that were the case, a particular element of the house—-such as a wall—or a pot, for example, 


\section{Acknowledgements}

Although my doctoral research was undertaken and completed at the École Pratique des Hautes Études (Paris) under Lyne Bansat-Boudon's supervision, I studied in Oxford under Alexis Sanderson's guidance in 2005 and 2006 while working on my $\mathrm{PhD}$ dissertation, and I am immensely indebted to him. He was kind enough not only to let me attend his classes there but also to organize many extra reading sessions so we could cover more of Abhinavagupta's İśvarapratyabhijñāoimarśinī, and we ended up reading about two thirds of this lengthy and difficult text in less than two years. It was an extraordinary experience for me, not only owing to Alexis's remarkable erudition and exceptional philological acumen, but also because his generosity, humour and curiosity have always created among his students a unique atmosphere of intellectual freedom and enthusiastic research. I am proud to consider myself a pupil of his, and it is a great honour and joy for me to be given this opportunity, by contributing to the present volume, to express my profound admiration and affection for this wonderful scholar and teacher.

Most of the research presented in this paper was carried out thanks to the generous financial help of the Deutsche Forschungsgemeinschaft, as part of project FR 2531/3-1. The National Mission for Manuscripts, the soAs Library and Mr. Chetan Pandey were kind enough to provide photographs of the manuscripts used for the edition of the fragments given below. Many thanks are also due to Vincent Eltschinger and Eli Franco, who read a draft of this paper and provided insightful remarks.

\section{References}

\section{Primary Sources: Manuscripts and Sigla}

D. İśvarapratyabhijñā[-Vrttii] Vivrti [and Vimarśinī]. Delhi: National Archives of India (Manuscripts belonging to the Archaeology and Research Department, Jammu and Kashmir Government, Srinagar), no. 3o, vol. Ix. Paper, Śāradā script.

although it is located inside the house, should be external to the house [since they are not the house itself]; and it is not so. And whereas that which is external to the house is next to the house, it is absolutely not the case as regards that which is [external] to consciousness, because of the impossibility for [consciousness] — which is devoid of material form (amürta — of having any spatial relation whatsoever such as proximity. Therefore this [externality] that must be established appears to be one thanks to a mere similarity (śabdasāmya)." 
D2. Íśvarapratyabhijñāvimarśinī. Delhi: National Archives of India (Manuscripts belonging to the Archeology and Research Department, Jammu and Kashmir Government, Srinagar), no. 5, vol. II. Paper, Saāradā script.

D3. Śivadrsțti. Delhi: National Archives of India (Manuscripts belonging to the Archeology and Research Department, Jammu and Kashmir Government, Srinagar), no. 7, vol. II. Paper, Sāadā script.

D4. Śivadrsțti. Delhi: National Archives of India (Manuscripts belonging to the Archeology and Research Department, Jammu and Kashmir Government, Srinagar), no. 83, vol. LXVI. Paper, Devanāgarī script.

J1o. İśvarapratyabhijñāvivrtivimarśinī. Jammu: Sri Ranbir Institute, Raghunath Mandir Library, no. 1475. Paper, Devanāgarī script.

J11. İśvarapratyabhijñāvivrtivimarśinī. Jammu: Sri Ranbir Institute, Raghunath Mandir Library, no. 5077. Paper, Devanāgarī script.

$\mathrm{J}^{\mathrm{R}}$. Íśvarapratyabhijñāvimarśinī. Jammu: Rashtriya Sanskrit Sansthan, no. 47 (formerly no. $5^{2 \mathrm{~A}}$ ) and no. $7 \mathrm{O}$ (formerly no. $5^{2 B}$ ). Paper, Śāradā script, incomplete.

S2. İśvarapratyabhijñāvimarśinī. Śrinagar: Oriental Research Library, no. 1035. Paper, Śāradā script.

S3. İśvarapratyabhijñāvimarśinī [catalogued as İśvarapratyabhijñākaumudī]. Śrinagar: Oriental Research Library, no. 838. Paper, Śāradā script.

S5. İśvarapratyabhijñāvimarśinī [catalogued as Sāṃkhyatattvakaumudī by Vācaspati Miśra; Abhinavagupta's ĪPV is copied after the latter]. Śrinagar: Oriental Research Library, no. 1212. Paper, Śāradā script.

S9. İśvarapratyabhijñāvimarśinī. Śrinagar: Oriental Research Library, no. 1161. Paper, Śāradā script.

S1o. İśvarapratyabhijñāvimarśinī. Śrinagar: Oriental Research Library, no. 1477. Paper, Śāradā script.

S12. Íśvarapratyabhijñāvivrtivimarśin̄̄ [catalogued as Íśvarapratyabhijñā(vimarśin̄̄)]. Srinagar: Oriental Research Library, no. 2403. Paper, Sāadā script.

S15. İ́varapratyabhijñāvimarśinī. Srinagar: Oriental Research Library, no. 787. Paper, Śāradā script.

S19. İśvarapratyabhijñāvrtti [catalogued as İśvarapratyabhijñāāârikā]. Srinagar: Oriental Research Library, no. 824. Paper, Śāradā script.

soAs. İ́varapratyabhijñāvimarśinī [catalogued as Pratyabhijñāsūtra with Abhinavagupta's Sūtrārthavimarśinī]. London: School of Oriental and African Studies Library, no. 44255/no. 207 in Dogra 1978. Paper, Śāradā script.

T. İśvarapratyabhijñāovivrtivimarśinī. Trivandrum: Oriental Research Institute and Manuscripts Library, no. 50413 B and C. Palm-leaf, Grantha Malayalam script. 


\section{Primary Sources: Edited Texts}

Abhidharmakośabhāṣya. Yasunori Ejima, ed. Abhidharmakośabhāṣya of Vasubandhu. Chapter I: Dhātunirdeśa. Bibliotheca Indologica et Buddhologica, no. 1. Tokyo: The Sankibo Press, 1989.

Āgamadambara. Csaba Dezső, ed. Unpublished critical edition and online supplemental materials available at http://www.claysanskritlibrary.org/extras.php\#11. Clay Sanskrit Library, 2004.

Granthibhanga. Gaurinath Sastri, ed. Nyāyamañjari of Jayanta Bhațta, with the Commentary of Granthibhanga by Cakradhara. 3 vols. Varanasi: Sampurnanand Sanskrit Vishvavidyalaya, 1982.

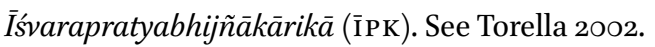

İ́varapratyabhijñāovimarśinī (ĪPv). Mukund Rām Shāstrī and Madhusudan Kaul Shāstrī, eds. İshvara-pratyabhijñā Vimarshinī of Utpaladeva [sic] With Commentary by Abhinava-Gupta. 2 vols. Kashmir Series of Texts and Studies, nos. 22 and 33. Bombay: Niraya Sagar Press, 1918-1921.

İ́varapratyabhijñāvivrtivimarśinī (ĪPVV). Madhusudan Kaul Shāstrī, ed. İśvarapratyabhijña Vivritivimarśinī of Abhinavagupta. 3 vols. Kashmir Series of Texts and Studies, nos. 6o, 62 and 65. Bombay: Nirnaya Sagar Press, 1938-1943.

Nyāyabhūṣaṇa. Svāmī Yogīndrānanda, ed. Śrīmadācāryabhāsarvajñapraṇìtasya nyāyasārasya svopajñam vyākhyānam nyāyabhūșaṇam. Varanasi: Ṣaḍdarśana Prakāśana Pratișțhānam, 1968.

Nyāyamañjarī. K.S. Varadacharya, ed. Nyāyamañjarī of Jayanta Bhațta, with TippaṇiNyāyasaurabha by the Editor. 2 vols. Oriental Research Institute Series, nos. 116 and 139. Mysore: Oriental Research Institute, 1969-1983.

Nyāyasūtra. Anantalal Thakur, ed. Gautamìyanyāyadarśana with Bhāșya of Vātsyāyana. Nyāyacaturgranthikā, no. 1. New Delhi: Indian Council of Philosophical Research, 1997.

Parātrīsikāvivaraṇa. Mukunda Rāma Shāstrī, ed. Parātrimshikā with Commentary, the Latter by Abhinavagupta. Kashmir Series of Texts and Studies, no. 18. Srinagar: Tatva Vivechaka Press, 1918.

Pramānaviniścaya. Ernst Steinkellner, ed. Dharmakīrti's Pramānaviniścaya, Chapters 1 and 2. Beijing-Vienna: China Tibetology Publishing House/Austrian Academy of Sciences Press, 2007.

Mālinīślokavārttika. Madhusudan Kaul Shastri, ed. Śrī Mālinìvijayavārttikam of Abhinavagupta. Kashmir Series of Texts and Studies, no. 32. Srinagar: Kashmir Pratap Steam Press, 1921.

Śivadrșți. Madhusudan Kaul Shastri, ed. Sivadrssți of Śrīsomānandanātha with the Vrtti by Utpaladeva. Kashmir Series of Texts and Studies, no. 54. Srinagar: 1934.

Śivadṛștivrtti. See Śivadrșți.

Spandapradīpikā. Mark S.G. Dyczkowski, ed. The Spandapradīpikā: A Commentary on the Spandakārikā by Bhagavadutpalācārya. Varanasi: D.K. Book Agencies, 1990. 
Svacchandatantroddyota. Madhusudan Kaul Shāstrī, ed. The Svacchanda Tantram with Commentary by Kșemarāja. 6 vols. Kashmir Series of Texts and Studies, nos. 31, 38, 44, 48, 53 and 56. Bombay: Nirnaya Sagar Press, 1921-1935.

Tantrāloka. Madhusudan Kaul Shāstrī, ed. Tantrāloka of Abhinavagupta with commentary by Rājānaka Jayaratha. 12 vols. Kashmir Series of Texts and Studies, nos. 23, 28, 29, 30, 35, 36, 41, 47, 52, 57, $5^{8}$ and 59. Allahabad: Indian Press, 1918-1938.

Tantrālokaviveka. See Tantrāloka.

Viṃsikā. Silvain Lévi, ed. Vijñaptimātratāsiddhi. Deux traités de Vasubandhu. Viṃśatikā (la vingtaine) accompagnée d'une explication en prose et Trimśikā (la trentaine) avec le commentaire de Sthiramati. Bibliothèque de l'École des Hautes Études 245. Paris: Honoré Champion, 1925 .

Viṃśikāvrtti. See Viṃśikā.

Vrtti (= Iśsvarapratyabhijñā vrtti). See Torella 2002.

\section{Secondary Sources}

Bhattacharya, Ramkrishna. 2002. "Cārvāka Fragments: a New Collection." Journal of Indian Philosophy 30 (6): 597-640.

Bronkhorst, Johannes. 20o8. “Udbhața, grammarian and Cārvāka." In Linguistic Traditions of Kashmir. Essays in Memory of Pandit Dinanath Yaksha, edited by Mrinal Kaul and Ashok Aklujkar, 281-299. Delhi: DK Printworld.

Bronner, Yigal. 2016. "Understanding Udbhața: the Invention of Kashmiri Poetics in the Jayāpịda Moment." In Around Abhinavagupta. Aspects of the Intellectual History of Kashmir from the Ninth to the Eleventh Century, edited by Eli Franco and Isabelle Ratié, 81-148. Berlin: Lit Verlag.

Dezső, Csaba. 2005. Much Ado about Religion by Bhațta Jayanta. New York: New York University Press/Jjc Foundation.

Dogra, R.C. 1978. A Handlist of the Manuscripts in South Asian Languages in the [soAs] Library. London: School of Oriental and African Studies.

Formigatti, Camillo. 2011. Sanskrit Annotated Manuscripts from Northern India and Nepal. PhD Dissertation. Hamburg: University of Hamburg.

Franco, Eli. 2011. "Lokāyata." In Brill's Encyclopedia of Hinduism, vol. III, edited by Knut A. Jacobsen, Helene Basu, Angelika Malinar and Vasudha Narayanan, 629-642. Leiden: Brill.

Iyer, K.A. Subramania. 1969. Bhartṛhari. A Study of the Vākyapadīya in the Light of the Ancient Commentaries. Poona: Deccan College.

Kano, Kazuo. 20o8. "Two short glosses on Yogācāra texts by Vairocanarakṣita: Viṃśikāțīkāvivrti and *Dharmadharmatāvibhāgavivrti." In Manuscripta Buddhica 1. Sanskrit Texts from Giuseppe Tucci's Collection, Part I, edited by Francesco Sferra, 343380. Roma: Istituto Italiano per l'Africa e l'Oriente.

Kapstein, Matthew T. 2001. Reason's traces. Identity and Interpretation in Indian and Tibetan Buddhist Thought. Boston: Wisdom Publications. 
Kawajiri, Yohei. 2016. "New Fragments of the İśvarapratyabhijñā-Tīkā." In Utpaladeva, Philosopher of Recognition, edited by Raffaele Torella and Bettina Bäumer, 77-101. Delhi: DK Printworld.

Kawajiri, Yohei. 2016b. "New Fragments of the İ́varapratyabhijñā-vivrti (3)." Nagoya Studies in Indian Culture and Buddhism (Sambhāsāa ) 33: 17-46.

Kellner, Birgit and John Taber. 2014. "Studies in Yogācāra-Vijñānavāda idealism I: The interpretation of Vasubandhu's Viṃśikā." Études Asiatiques/Asiatische Studien 68 (3): 709-756.

La Vallée Poussin, Louis de. 1923. L'Abhidharmakośa de Vasubandhu, traduit et annoté, Premier et deuxième Chapitres. Paris: Paul Geuthner.

McCrea, Lawrence and Parimal Patil. 2010. Buddhist Philosophy of Language in IndiaJñannaśrimitra on Exclusion. New York: Columbia University Press.

McCrea, Lawrence. 2016. "Abhinavagupta as Intellectual Historian of Buddhism." In Around Abhinavagupta. Aspects of the Intellectual History of Kashmir from the gth to the nth Century, edited by Eli Franco and Isabelle Ratié, 263-286. Berlin: Lit Verlag.

Namai, Mamoru. 1976. "Kōki Bukkyōto ni yoru Bārhaspatya Hihan (I)." Indological Review 2: 33-74.

Nemec, John. 2011. The Ubiquitous Śiva. Somānanda’s Śivadṛști and his Tantric Interlocutors. Oxford; New York: Oxford University Press.

Preisendanz, Karin. 1989. "On ātmendriyamanorthasannikarșa and the Nyāya-Vaiśeșika Theory of Vision." Berliner Indologische Studien 4-5: 141-213.

Ratié, Isabelle. 2010. "The Dreamer and the Yogin—on the Relationship between Buddhist and Śaiva Idealisms." Bulletin of the School of Oriental and African Studies 73 (3): 437-478.

Ratié, Isabelle. 2010b. “'A Five-trunked, Four-tusked Elephant is Running in the Sky' How Free is Imagination According to Utpaladeva and Abhinavagupta?" Asiatische Studien/Études Asiatiques 64 (2): 341-385.

Ratié, Isabelle. 2011. Le Soi et l'Autre. Identité, différence et altérité dans la philosophie de la Pratyabhijñā. Leiden; Boston: Brill.

Ratié, Isabelle. 2011b. "Can One Prove that Something Exists Beyond Consciousness? A Śaiva Criticism of the Sautrāntika Inference of External Objects." Journal of Indian Philosophy 39 (4-5): 479-501.

Ratié, Isabelle. 2014. "On the Distinction between Buddhist Epistemic and Metaphysical Idealisms: a Śaiva Perspective." Journal of Buddhist Philosophy 42: 353-375.

Ratié, Isabelle. 2016. "Some Hitherto Unknown Fragments of Utpaladeva's Vivrti (I): on the Buddhist Controversy over the Existence of Other Conscious Streams." In Utpaladeva, Philosopher of Recognition, edited by Raffaele Torella and Bettina Bäumer, 224-256. Delhi: DK Printworld.

Ratié, Isabelle. 2016b. "Some Hitherto Unknown Fragments of Utpaladeva's Vivrti (III): on Memory and Error." In Around Abhinavagupta. Aspects of the Intellectual History 
of Kashmir from the gth to the nth Century, edited by Eli Franco and Isabelle Ratié, 375-40o. Berlin: Lit Verlag.

Ratié, Isabelle. 2017. "In Search of Utpaladeva's Lost Vivrti on the Pratyabhijñā Treatise: a Report on the Latest Discoveries (with the Vivrti on the end of Chapter 1.8)." Journal of Indian Philosophy 45: 163-189.

Ratié, Isabelle. 2018. "On the Șaḍdhātusamīkșā, a Lost Work Attributed to Bhartṛhari: an Examination of Testimonies and a List of Fragments." Journal of the American Oriental Society 138 (4): 709-742.

Ratié, Isabelle. 2018b. "For an Indian Philology of Margins: The Case of Kashmirian Sanskrit Manuscripts." In L'espace du Sens: Approches de la philologie indienne. The Space of Meaning: Approaches to Indian Philology, edited by Silvia d'Intino and Sheldon Pollock, with the collaboration of Michaël Meyer, 305-354. Paris: Collège de France/Diffusion De Boccard.

Ratié, Isabelle. Forthcoming. Utpaladeva on the Power of Action: a First Edition, Annotated Translation and Study of Íśvarapratyabhijñāvivrti, Chapter 2.1.

Solomon, Esther A. 1977-1978. "Bhațta Udbhața." Annals of the Bhandarkar Oriental Research Institute 58-59: 985-992.

Torella, Raffaele. 1988. "A Fragment of Utpaladeva's İśvarapratyabhijñā-vivrti." East and West 38: 137-174.

Torella, Raffaele. 1992. "The Pratyabhijñā and the Logical-Epistemological School of Buddhism." In Ritual and Speculation in Early Tantrism, Studies in Honor of André Padoux, edited by Teun Goudriaan, 327-345. Albany: State University of New York Press.

Torella, Raffaele. 2002. İśvarapratyabhijñākārikā of Utpaladeva with the Author's Vrtti, Critical Edition and Annotated Translation. Corrected edition, Delhi: Motilal Banarsidass [Roma: 1994].

Torella, Raffaele. 2007a. "Studies on Utpaladeva's İsvarapratyabhijñā-vivrti. Part I: anupalabdhi and apoha in a Śaiva Garb." In Expanding and Merging Horizons. Contributions to South Asian and Cross-Cultural Studies in Commemoration of Wilhelm Halbfass, edited by Karin Preisendanz, 473-49o. Wien: Verlag der Österreichischen Akademie der Wissenschaften.

Torella, Raffaele. 2007b. “Studies on Utpaladeva's İ́varapratyabhijñā-vivrti. Part II: What is memory?" In Indica et Tibetica. Festschrift für Michael Hahn zum 65. Geburtstag von Freunden und Schülern überreicht, edited by Konrad Klaus and Jens-Uwe Hartmann, 539-563. Wien: Arbeitskreis für tibetische und buddhistische Studien Universität Wien.

Torella, Raffaele. 2007c. "Studies on Utpaladeva's İśvarapratyabhijñāa-vivrti. Part III. Can a Cognition Become the Object of Another Cognition?” In Mélanges tantriques à la mémoire d'Hélène Brunner, edited by Dominic Goodall and André Padoux, 475-484. Pondicherry: Institut Français de Pondichéry/École Française d'Extrême-Orient. 
Torella, Raffaele. 2007d. "Studies on Utpaladeva's Íśvarapratyabhijñā-vivrti. Part IV. Light of the Subject, Light of the Object." In Pramānakirtih. Papers dedicated to Ernst Steinkellner on the Occasion of his 7oth Birthday, edited by Birgit Kellner, Helmut Krasser and Helmut Tauscher, 925-940. Wien: Arbeitskreis für tibetische und buddhistische Studien Universität Wien.

Torella, Raffaele. 2014. "Notes on the Śivadrssți by Somānanda and its Commentary." Journal of Indian Philosophy 42: 551-601. 